Review

\title{
Environmental/Occupational Exposure to Radon and Non-Pulmonary Neoplasm Risk: A Review of Epidemiologic Evidence
}

\author{
Paola Mozzoni ${ }^{1,2}{ }^{\oplus}$, Silvana Pinelli ${ }^{1}$, Massimo Corradi ${ }^{1,2}$, Silvia Ranzieri ${ }^{1} @$, Delia Cavallo ${ }^{3}$ and Diana Poli ${ }^{3, *}$ \\ 1 Department of Medicine and Surgery, University of Parma, 43126 Parma, Italy; paola.mozzoni@unipr.it (P.M.); \\ silvana.pinelli@unipr.it (S.P.); massimo.corradi@unipr.it (M.C.); silvia.ranzieri@unipr.it (S.R.) \\ 2 Centre for Research in Toxicology (CERT), University of Parma, Via A. Gramsci 14, 43126 Parma, Italy \\ 3 INAIL Research, Department of Occupational and Environmental Medicine, Epidemiology and Hygiene, \\ Via Fontana Candida 1, 00078 Monte Porzio Catone, Italy; d.cavallo@inail.it \\ * Correspondence: d.poli@inail.it
}

check for updates

Citation: Mozzoni, P.; Pinelli, S.; Corradi, M.; Ranzieri, S.; Cavallo, D.; Poli, D. Environmental/Occupational Exposure to Radon and Non-Pulmonary Neoplasm Risk: A Review of Epidemiologic Evidence. Int. J. Environ. Res. Public Health 2021, 18, 10466. https://doi.org/10.3390/ ijerph181910466

Academic Editor: Paul B. Tchounwou

Received: 7 September 2021

Accepted: 29 September 2021

Published: 5 October 2021

Publisher's Note: MDPI stays neutral with regard to jurisdictional claims in published maps and institutional affiliations.

Copyright: (c) 2021 by the authors. Licensee MDPI, Basel, Switzerland. This article is an open access article distributed under the terms and conditions of the Creative Commons Attribution (CC BY) license (https:// creativecommons.org/licenses/by/ $4.0 /)$.

\begin{abstract}
Although Radon (Rn) is a known agent for lung cancer, the link between Rn exposure and other non-pulmonary neoplasms remains unclear. The aim of this review is to investigate the role of $\mathrm{Rn}$ in the development of tumors other than lung cancer in both occupational and environmental exposure. Particularly, our attention has been focused on leukemia and tumors related to brain and central nervous system (CNS), skin, stomach, kidney, and breast. The epidemiologic literature has been systematically reviewed focusing on workers, general population, and pediatric population. A weak increase in leukemia risk due to Rn exposure was found, but bias and confounding factors cannot be ruled out. The results of studies conducted on stomach cancer are mixed, although with some prevalence for a positive association with Rn exposure. In the case of brain and CNS cancer and skin cancer, results are inconclusive, while no association was found for breast and kidney cancers. Overall, the available evidence does not support a conclusion that a causal association has been established between Rn exposure and the risk of other non-pulmonary neoplasms mainly due to the limited number and heterogeneity of existing studies. To confirm this result, a statistical analysis should be necessary, even if it is now not applicable for the few studies available.
\end{abstract}

Keywords: radon; epidemiological studies; cancer risk; environmental exposure; occupational exposure

\section{Introduction}

Radon (Rn), a colorless and odorless radioactive noble gas, originated from the decay of Uranium (U) and Thorium (Th), is found in rocks and soil. Soil is responsible for about $80 \%$ of the $\mathrm{Rn}$ in atmosphere, water contributes to $19 \%$, and other sources for only $1 \%$ [1]. Rn concentration in air depends on the intensity of the source and on dilution factors, both strongly influenced by weather conditions, such as humidity, atmospheric pressure, and wind conditions. Therefore, Rn levels exhibit both daily and seasonal variations, which are often cyclical [2].

Three are the main naturally occurring isotopes of $\mathrm{Rn}:{ }^{219} \mathrm{Rn}$ (also known as thoron); ${ }^{220} \mathrm{Rn}$ (also called actinon); and ${ }^{222} \mathrm{Rn}$, arising from the decay of ${ }^{235} \mathrm{U},{ }^{232} \mathrm{Th}$, and ${ }^{238} \mathrm{U}$, respectively (Figure 1) [3]. The amount of ${ }^{219} \mathrm{Rn}$ and ${ }^{220} \mathrm{Rn}$ in air pollution is small due to their short half-life (3.96 s, and $55.6 \mathrm{~s}$, respectively) that limits their diffusion in the atmosphere before decay. In addition, the scarcity of ${ }^{235} \mathrm{U}$ makes the role of ${ }^{219} \mathrm{Rn}$ negligible. Therefore, the lack of knowledge about ${ }^{219} \mathrm{Rn}$ and ${ }^{220} \mathrm{Rn}$ potential human health effects is due to their unlikely environmental accumulation with consequently reduced human exposure [4], even if their environmental evidence and detrimental effect on human health are described in literature [5]. Most of the radioactivity in the atmosphere attributable to ${ }^{222} \mathrm{Rn}$ is due to its longer half-life (3.82 days) that allows its diffusion from environment to 
dwellings. ${ }^{222} \mathrm{Rn}$ decays into more chemically reactive progeny such as ${ }^{218}$ Polonium (Po), ${ }^{214} \mathrm{Lead}(\mathrm{Pb}),{ }^{214}$ Bismuth (Bi), and ${ }^{214} \mathrm{Po}$ (half-life equal to 3,1 $\mathrm{min} ; 26,8 \mathrm{~min} ; 19,9 \mathrm{~min}$; and $1664 \mu \mathrm{s}$, respectively), which are able to emit dangerous $\alpha$ and $\beta$ radiation. Additionally, ${ }^{218} \mathrm{Po}$ and ${ }^{214} \mathrm{~Pb}$ are solids that may spread out in the atmosphere by attaching themselves to air particulate and then settle in soil or water through mechanisms of deposition or the action of rain [6,7].

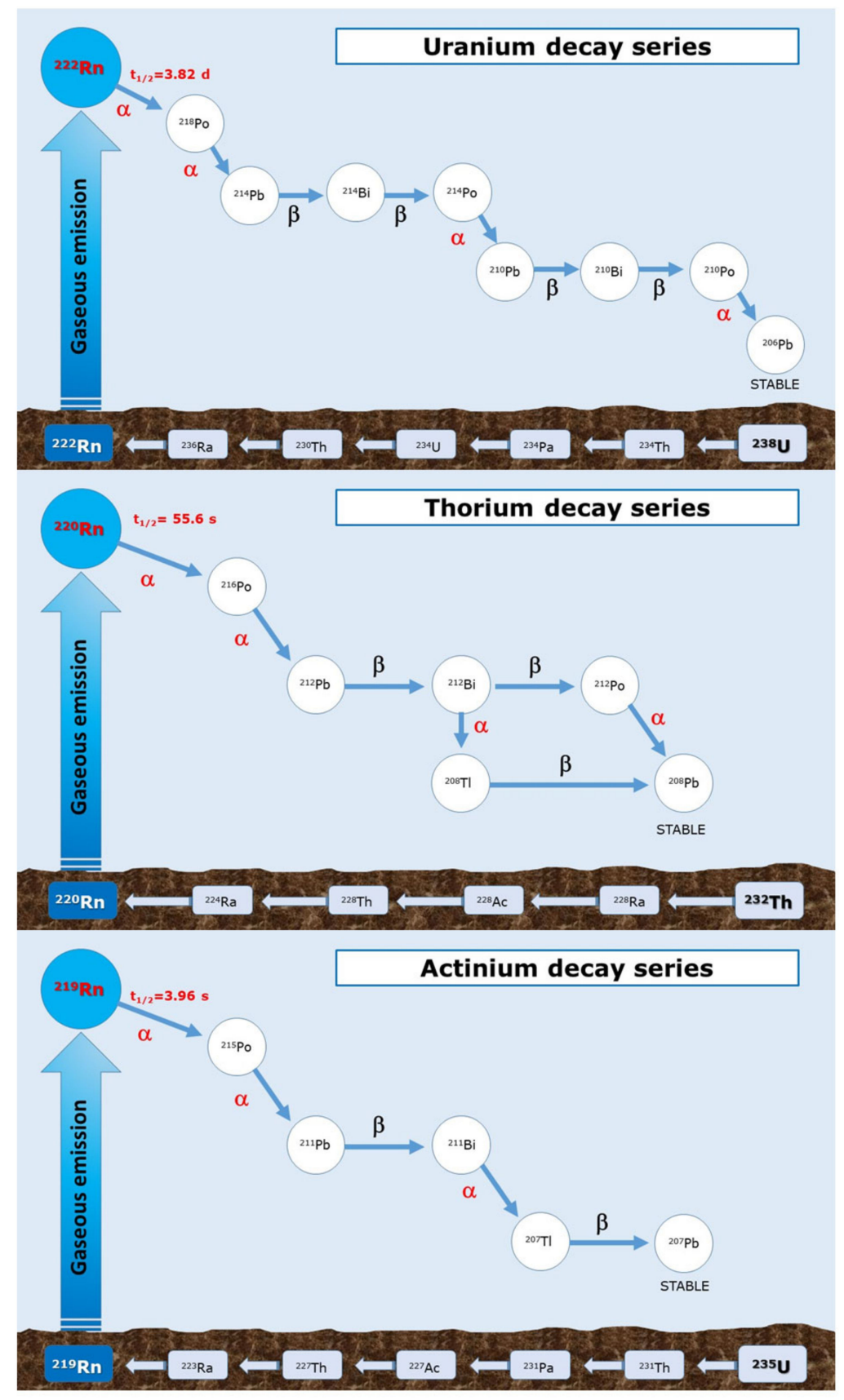

Figure 1. Decay series of Uranium, Thorium, and Actinium. $\mathrm{Pa}=$ Protactin, $\mathrm{Ac}=$ Actinium, $\mathrm{Ra}=$ Radium, $\mathrm{Tl}=$ Tallium.

The concentration of Rn outdoors is typically low and, in any case, does not exceed a few tens of $\mathrm{Bq} / \mathrm{m}^{3}$ (See Appendix A for Radon measurement units). In fact, Rn escaping from the ground is diluted in a very large volume of air and is rapidly degraded in the atmosphere. On the other hand, in closed places (e.g., homes, offices, schools, etc.) levels vary from a few tens to a few hundred $\mathrm{Bq} / \mathrm{m}^{3}$, reaching sometimes thousands of $\mathrm{Bq} / \mathrm{m}^{3}$ [8]. 
Human exposure occurs primarily through inhalation and ingestion, the latter given by Rn dissolved in groundwater. In the field of occupational exposure, high Rn concentrations can be detected in underground places with poor ventilation and in water treatment plants [9]. The highest concentrations to which workers might be frequently exposed occur in mines; in fact, the first studies related to the effects of Rn exposure have been conducted among miners of the underground mines of uranium [10]. As far as the general population is concerned, Rn exposure is mainly due to its presence in dwellings. Rn levels in building vary regionally and according to season and housing characteristics, with higher concentrations in colder months, in homes with poor ventilation, and on the lower floors of houses [11-14]. Rn enters buildings through various routes, such as cracks in solid floors, construction joints, cracks in walls above and below ground level, gaps in suspended floors, gaps around service pipes and cavities in the walls [15]. Another cause is the depression created between the various rooms and the ground, induced primarily by the temperature difference between the internal and external environment. The pressure difference determines an upward flow of air from the ground (movement from a high to a low-pressure area), causing the chimney effect [16]. In addition, Rn dissolved in groundwater can be released into indoor air during domestic water use, such as cooking, showering, clothes washing, or water boiling, thereby increasing the total inhalation risk [17-19].

Because of its presence in living and working environments and its effects on human health, specific laws and regulations have been produced in many countries. Most European States and many non-European countries recommended reference levels for dwellings and workplaces, and some embraced guidelines for construction techniques and for Rn risk management incorporated in the building codes. In Europe, the International Commission on Radiological Protection (ICRP) and The Council of the European Union (EU) have recommended the Member States to take action against Rn in homes and at workplaces. Several European Directives have been succeeded by lowering the limits required for $\mathrm{Rn}$ (e.g., 96/143, 96/29, 2013/59). Consequently, each Member State had to lay down the appropriate provisions, whether by legislation, regulation, or administrative action, to ensure compliance with the basic standards, which have been established. In particular, Council Directive 90/143/Euratom recommendation about indoor Rn in dwellings suggested an average concentration of $200 \mathrm{~Bq} / \mathrm{m}^{3}$ for new dwellings and $400 \mathrm{~Bq} / \mathrm{m}^{3}$ in existing dwellings as level for considering remedial action (90/143/Euratom) [20]. The European Council Directive 96/29/Euratom had stipulated that Member States should have required the carrying out of practices for monitoring work activities linked to a significant increase in worker' exposure (96/29/Euratom) [21] Later, the Council Directive 2013/59/Euratom laying down basic safety standards for protection against the dangers arising from exposure to ionizing radiation repealed Directive 96/29/Euratom establishing $300 \mathrm{~Bq} / \mathrm{m}^{3}$ as a concentration threshold for both dwellings and workplaces in all EU countries. (2013/59/Euratom) [22]. In the United States, where generally the Rn level is measured in $\mathrm{pCi} / \mathrm{L}$ (i.e., $\mathrm{Ci}=$ Curie that represents the activity of one gram of $\mathrm{Rn}$ in radioactive equilibrium; $\mathrm{pCi}=$ equivalent to $10^{-12}$ Curie; $\left.1 \mathrm{pCi} / 1=37 \mathrm{~Bq} / \mathrm{m}^{3}\right)$, a Rn level below $2 \mathrm{pCi} / \mathrm{L}\left(74 \mathrm{~Bq} / \mathrm{m}^{3}\right.$ ) is accepted as normal (Radon Zone 3), while an indoor level between 2 and $4 \mathrm{pCi} / \mathrm{L}\left(74-148 \mathrm{~Bq} / \mathrm{m}^{3}\right)$ is designated as Radon Zone 2 at which the USEPA suggests to perform mitigation. An indoor Rn level above $4 \mathrm{pCi} / \mathrm{L}\left(148 \mathrm{~Bq} / \mathrm{m}^{3}\right.$ ) (Action Level) is categorized as Radon Zone 1 where mitigation is deemed necessary because an increased risk for lung cancer has been observed at that exposure level [23]. In Western Australia, the management of radioactive materials is governed by the Radiation Safety Act (1975) [24], and the specific provisions relating to the management of naturally occurring radioactive materials in mining operations are included in the Mines Safety and Inspection Act (1994) [25] and Regulations (1995) [26] which specify the same dose limits for exposed workers. Specifically, the effective dose for workers must not exceed $50 \mathrm{mSv}$ (i.e., $\mathrm{Sv}=$ Sievert: unit of measurement equal to the absorbed dose of any ionizing radiation having the same biological efficacy as 1 gray of X-rays) in a single year and $100 \mathrm{mSv}$ over a period 
of five consecutive years. From this scenario, it is clear how Rn mitigation requirements in most states vary substantially. These discrepancies have public health implications. The influence of EU Directives on Rn exposure may have relevance as a model for standardized international regulations. This is why it would be important to harmonize limit value. A Rn assessment is essential because it allows to obtain information on indoor Rn concentration distribution which are useful for decision making (e.g., for establishing reference levels, for individuation of Rn priority areas).

The concern about occupational and environmental exposure arises from the fact that $\mathrm{Rn}$ and its short-lived decay products have been classified as a known pulmonary carcinogen in humans by the International Agency of Research on Cancer since 1988 [27].

Epidemiologic studies support a relationship between Rn exposure and cancer risk, in particular for lung cancer [28-30]. Although it is conceivable that Rn may have a role in other cancer diseases, the epidemiologic evidence is not so strong such as for lung cancer. One reason is that due to the bio-kinetics of Rn inhalation in the body, the effective radiation doses reaching specific organs is several times lower than that received by the lungs. Furthermore, there is a lower number of scientific publications studying the relationship between $\mathrm{Rn}$ and risks other than lung cancer. For the latter, the average of publications on the main databases such as Pubmed [31], Scopus [32], and Web of Sciences [33] is $18.1 \%$, while for the only Rn lung cancer it reaches $81.9 \%$. In addition, most of these studies evaluate the effect of Rn exposure on multiple organs focusing mostly on the lung and making the extrapolation of the results difficult.

The aim of this review is to analyze the epidemiologic evidence in order to investigate the role of $\mathrm{Rn}$ in the development of tumors other than lung cancer in both occupational and environmental exposure. Particularly, leukemia and tumors related to brain and central nervous system (CNS), skin, stomach, kidney, and breast have been investigated focusing on workers, general population, and pediatric population.

\section{Materials and Methods}

Published reviews of the epidemiology of Rn that formed the basis of our literature search were by the World Health Organization [28], United States Environmental Protection Agency (USEPA) [34], National Council on Radiation Protection and Measurements (NCRP) [35], National Research Council (NRC) [36], International Agency for Research on Cancer (IARC) [37], and National Institute for Occupational Safety and Health Technical Information Center (NIOSHTIC) [38].

Furthermore, a systematic literature search using PubMed, Scopus, and Web of Science databases was performed with the terms and phrases: "radon" and "cancer", or "other than lung cancer", or "brain and Central Nervous System (CNS) cancer", or "leukemia", or "skin cancer", or "stomach cancer", or "breast cancer", or "occupational exposure", or "environmental exposure". We included original articles, reviews, and meta-analyses published in the English language until 2020. The literature was also searched for regulations related to Rn both in occupational and environmental exposure. We completed the search through consulting manually the references of the papers selected to be full-text read.

\section{Results}

Publications have been analyzed focusing on workers and general and pediatric populations.

\subsection{Brain and Central Nervous System (CNS) Cancer}

Results are summarized in Table $1 \mathrm{a}-\mathrm{c}$.

\subsubsection{Workers}

Almost all studies in working population were performed in miners. In 1995, Tirmarche et al. studied French uranium miners exposed to Rn concentrations range from 500 to $1000 \mathrm{~Bq} / \mathrm{m}^{3}$ in order to calculate the number of expected deaths due to brain cancer. Combined malignant brain tumor, malignant tumors of other parts of the nervous system, 
and tumors of unspecified nature of the brain and other parts of the nervous system were investigated. A significant risk of death $(p$-value $=0.03$ ) has been calculated only by excluding the last group (i.e., tumors of unspecified nature of the brain and other parts of the nervous system) [39]. Darby et al. examined mortality from non-lung cancer in an analysis of data from 11 cohorts of underground miners in which Rn-related excess of lung cancer had been established. The study included 64,209 men employed in the mines for 6.4 years on average, receiving average cumulative exposures of 155 working-level months (WLM), and were followed for 16.9 years on average. This study provides considerable evidence that high concentrations of $\mathrm{Rn}$ in air do not cause a risk of mortality from cancers other than lung cancer, including brain and CNS cancers [40]. Similarly, in a cohort of iron miners from northern Sweden occupationally exposed to elevated levels of $\mathrm{Rn}$, the mortality was increased for all cancers other than lung cancer, but it was not significantly associated with cumulative exposure to Rn [41]. About ten years later, Vacquier and co-authors in a first study on a cohort of men employed as uranium miners between 1946 and 1990 highlighted a significant excess risk of cancer death for a lung (associated with levels of cumulated radon exposure) and kidney (not associated with radon exposure), but the brain and CNS cancer had not been included [42]. In a later paper, the same authors examined the mortality risks associated with exposure to Rn, external $\gamma$-rays, and long-lived radionuclides (LLR) in the French "post-55" sub-cohort, including uranium miners first employed between 1956 and 1990 for whom all three types of exposure were individually assessed. The study highlighted for the first time an increase of mortality for brain and CNS cancer (SMR: 2.00; 95\% CI: 1.09-3.35) [45].

Table 1. Brain and Central Nervous System (CNS) cancer.

\begin{tabular}{|c|c|c|c|c|}
\hline \multicolumn{5}{|c|}{ a: Workers } \\
\hline Study Design & $\begin{array}{c}\text { Sample Size } \\
(n)\end{array}$ & $\begin{array}{l}\text { Radon } \\
\text { Conc. }\end{array}$ & Results & $\begin{array}{l}\text { Reference } \\
\text { (Year) }\end{array}$ \\
\hline $\begin{array}{l}\text { Cohort mortality } \\
\text { study }\end{array}$ & 1785 & 70.4 WLM $^{1}$ & $\begin{array}{c}\text { SMR: } 1.89 ; 95 \% \text { CI: } 0.78-3.89 \\
\text { Expected number of deaths }{ }^{3}: \\
\quad p \text {-value }=0.03\end{array}$ & $\begin{array}{c}\text { Tirmarche et al. (1993) } \\
\text { [39] }\end{array}$ \\
\hline $\begin{array}{l}\text { Cohort mortality } \\
\text { study }\end{array}$ & 64,209 & $155 \mathrm{WLM}^{1}$ & $\begin{array}{c}\text { O/E deaths }{ }^{4}: 1.01 ; 95 \% \mathrm{CI}: \\
0.95-1.07 \\
\text { No significant association }\end{array}$ & $\begin{array}{l}\text { Darby et al. } \\
(1995) \text { [40] }\end{array}$ \\
\hline $\begin{array}{l}\text { Cohort mortality } \\
\text { study }\end{array}$ & 1294 & 89 WLM $^{1}$ & $\begin{array}{c}\text { O/E deaths }{ }^{4}: 1.21 ; 95 \% \text { CI } \\
1.03-1.41 \\
\text { No significant association }\end{array}$ & $\begin{array}{l}\text { Darby et al. } \\
\text { (1995) [41] }\end{array}$ \\
\hline Cohort study & $\begin{array}{l}5086 \text { (4140 exposed } \\
\text { to radon) }\end{array}$ & $36.6 \mathrm{WLM}^{1}$ & No significant association & $\begin{array}{l}\text { Vacquier et al. } \\
\text { (2008) [42] }\end{array}$ \\
\hline Cohort study & $\begin{array}{c}49,268 \mathrm{Ex}-\mathrm{E} \\
7931 \mathrm{NE}\end{array}$ & $279.4 \mathrm{WLM}^{2}$ & O/E ${ }^{4}: 1.02 ; 95 \%$ CI: 0.98-1.05 & $\begin{array}{l}\text { Kreuzer et al. } \\
(2008)[43]\end{array}$ \\
\hline Cohort study & 4137 & 794-808 WLM & No significant association & $\begin{array}{l}\text { Schubauer-Berigan } \\
\text { et al. } \\
\text { (2009) [44] }\end{array}$ \\
\hline Cohort study & 3377 & 17.8 WLM $^{1}$ & SMR: $2.00 ; 95 \%$ CI: 1.09-3.35 & $\begin{array}{l}\text { Vacquier et al. } \\
\text { (2011) [45] }\end{array}$ \\
\hline \multicolumn{5}{|c|}{ b: General Population } \\
\hline Study Design & $\begin{array}{l}\text { Sample Size } \\
(n)\end{array}$ & $\begin{array}{l}\text { Radon } \\
\text { Conc. }\end{array}$ & Results & $\begin{array}{l}\text { Reference } \\
\text { (Year) }\end{array}$ \\
\hline Prospective study & 811,961 & $\begin{array}{l}\text { mean } \pm \text { s.d: } 53.5 \pm 38.0 \\
\mathrm{~Bq} / \mathrm{m}^{3} \text { range: } 6.3-265.7\end{array}$ & $\begin{array}{c}\text { HR: } 0.98 \text { per } 100 \mathrm{~Bq} / \mathrm{m}^{3} \\
\text { 95\% CI: } 0.83-1.15 \\
\text { No clear associations }\end{array}$ & $\begin{array}{l}\text { Turner et al. } \\
\text { (2012) [46] }\end{array}$ \\
\hline Cohort study & 57,053 & $40.5 \mathrm{~Bq} / \mathrm{m}^{3}$ & IRR: 1.96; 95\% CI: 1.07-3.58 & $\begin{array}{l}\text { Bräuner et al. } \\
\text { (2013) [47] }\end{array}$ \\
\hline
\end{tabular}


Table 1. Cont.

\begin{tabular}{|c|c|c|c|c|}
\hline \multicolumn{5}{|c|}{ b: General Population } \\
\hline Study Design & $\begin{array}{l}\text { Sample Size } \\
(n)\end{array}$ & $\begin{array}{l}\text { Radon } \\
\text { Conc. }\end{array}$ & Results & $\begin{array}{l}\text { Reference } \\
\text { (Year) }\end{array}$ \\
\hline Ecological study & 251 & GM: $100-200 \mathrm{~Bq} / \mathrm{m}^{3}$ & $\begin{array}{c}\text { Spearman's Rho: } \\
0.286 \text { (males; } p \text {-value: }<0.001 ;) \\
0.509 \text { (females; } p \text {-value: }<0.001 \text { ) }\end{array}$ & $\begin{array}{l}\text { Ruano-Ravina et al. } \\
\text { (2017) [48] }\end{array}$ \\
\hline Ecological study & 13 & $153.9 \mathrm{~Bq} / \mathrm{m}^{3}$ & $\begin{array}{c}\text { RR: } 1.28 \\
\text { Statistical association }\end{array}$ & $\begin{array}{l}\text { López-Abente et al. } \\
\text { (2018) [49] }\end{array}$ \\
\hline Ecological study & $\begin{array}{c}\text { New Jersey: } 14,662 ; \\
\text { Iowa: } 8429 ; \\
\text { Wisconsin: } 8023 ; \\
\text { Pennsylvania: } \\
\text { 22,940; Minnesota: } \\
\text { 5338 }\end{array}$ & $4.6-8.6 \mathrm{pCi} / \mathrm{L}$ & $\begin{array}{l}\text { Negative association: } p \text {-value } \\
\qquad<0.0001\end{array}$ & $\begin{array}{l}\text { Monastero et al. } \\
\text { (2020) [50] }\end{array}$ \\
\hline \multicolumn{5}{|c|}{ c: Pediatric Population } \\
\hline Study design & $\begin{array}{l}\text { Sample Size } \\
(n)\end{array}$ & $\begin{array}{l}\text { Radon } \\
\text { Conc. }\end{array}$ & Results & $\begin{array}{l}\text { Reference } \\
\text { (Year) }\end{array}$ \\
\hline Ecological study & $\begin{array}{l}\text { Total death: } 2706 \\
\text { Brain and CNS } \\
\text { disease: } 454\end{array}$ & $0-10,692 \mathrm{pCi} / 1^{1}$ & $\begin{array}{c}\text { Medium exposure } \\
\text { RR: } 1.28 ; 95 \% \text { CI: } 1.00-1.62 \\
\text { High exposure } \\
\text { RR: } 1.18 ; 95 \% \text { CI: } 0.90-1.54\end{array}$ & $\begin{array}{l}\text { Collman et al. } \\
\text { (1991) [51] }\end{array}$ \\
\hline Case-control study & $\begin{array}{l}82 \mathrm{~L} ; 82 \mathrm{ST} ; 209 \\
\text { Controls }\end{array}$ & $\begin{array}{c}\text { mean: } 27 \mathrm{~Bq} / \mathrm{m}^{3} \\
\text { range: } 10-584 \mathrm{~Bq} / \mathrm{m}^{3}\end{array}$ & $\begin{array}{c}\text { Solid Tumor } \\
\text { OR: } 2.61 ; 95 \% \text { CI: } 0.96-7.13\end{array}$ & $\begin{array}{l}\text { Kaletsch et al. } \\
\text { (1999) [52] }\end{array}$ \\
\hline Case-control study & $\begin{array}{l}\text { Cases: } 2400 \\
\text { Controls: } 6697\end{array}$ & $\begin{array}{c}\text { mean: } 48 \mathrm{~Bq} / \mathrm{m}^{3} \\
\text { range: } 4-254 \mathrm{~Bq} / \mathrm{m}^{3}\end{array}$ & No significant association & $\begin{array}{l}\text { Raaschou-Nielsen et al. } \\
\text { (2008) [53] }\end{array}$ \\
\hline Cohort study & $\begin{array}{l}\text { Childhood cancer } \\
\text { cases: } 997\end{array}$ & $\begin{array}{l}\text { median: } 77.7 \mathrm{~Bq} / \mathrm{m}^{3} \\
\text { 90th: } 139.9 \mathrm{~Bq} / \mathrm{m}^{3}\end{array}$ & $\begin{array}{c}\text { All cancers } \\
\text { HR: } 0.93 ; 95 \% \text { CI: } 0.74-1.16 \\
\text { CNS tumors } \\
\text { HR: } 1.05 ; 95 \% \text { CI: } 0.68-1.61\end{array}$ & $\begin{array}{l}\text { Hauri D et al. } \\
\text { (2013) [54] }\end{array}$ \\
\hline Case-control study & $\begin{array}{l}\text { Cases: } 27,447 \\
\text { Controls: } 36,793\end{array}$ & mean: $22 \mathrm{~Bq} / \mathrm{m}^{3}$ & $\begin{array}{c}\text { ERR: } 3 \% \text {; } 95 \% \text { CI: } 4-11 ; \\
\quad p \text {-value: } 0.35\end{array}$ & $\begin{array}{l}\text { Kendall et al. } \\
\text { (2013) [55] }\end{array}$ \\
\hline Cohorts & $\begin{array}{c}\text { Total: } 712,674 \\
\text { Cancer cases: } 864\end{array}$ & $\begin{array}{l}\text { mean: } 91 \mathrm{~Bq} / \mathrm{m}^{3} \\
\text { median: } 74 \mathrm{~Bq} / \mathrm{m}^{3}\end{array}$ & $\begin{array}{c}<50 \mathrm{~Bq} / \mathrm{m}^{3} \mathrm{HR}: 1.00 \text { (Ref.) } \\
50-100 \mathrm{~Bq} / \mathrm{m}^{3} \mathrm{HR}: 0.88 ; \mathrm{CI}: \\
\quad(0.68-1.14) \\
>100 \mathrm{~Bq} / \mathrm{m}^{3} \mathrm{HR}: 1.15 ; \mathrm{CI}: \\
\quad(0.87-1.50) \\
\text { No significant association }\end{array}$ & $\begin{array}{l}\text { Del Risco Kollerud et al. } \\
\text { (2014) [56] }\end{array}$ \\
\hline Ecological study & 5471 cases of CNST & ${ }^{1} 41.0 \mathrm{~Bq} / \mathrm{m}^{3}$ & $\begin{array}{l}\text { IRR: } 1.07 ; \mathrm{CI}: 0,95-1.20 \text { per } \\
100 \mathrm{~Bq} / \mathrm{m}^{3} \\
\text { No significant association }\end{array}$ & $\begin{array}{l}\text { Berlivet J et al. } \\
\text { (2020) [57] }\end{array}$ \\
\hline
\end{tabular}

a: ${ }^{1}$ Average cumulative exposure; ${ }^{2}$ accumulated exposure; ${ }^{3}$ malignant brain tumor and malignant tumors of other parts of the nervous system; ${ }^{4}$ for all other than lung cancer combined; WLM: Working Level Month; Ex-E: ex esposed; NE: never exposed; O/E: observed/expected cases; 95\% CI: 95\% confidence interval; SMR: Standardized Mortality Ratio. b: IRR: incidence rate-ratios; RR: Relative Risk; GM: geometric mean; 95\% CI: 95\% confidence interval; HR: Hazard Ratio. c: ${ }^{1}$ drinking water; L: leukemias; ST: solid tumors; IRR: incidence rate-ratios; RR: Relative Risk; 95\% CI: 95\% confidence interval; HR: Hazard Ratio; OR: odds ratio; ERR: excess relative risk.

On the contrary, the cohort of uranium miners examined from Kreuzer et al., which included 58,987 men employed for at least 6 months from 1946 to 1989 in an uranium mining company in Eastern Germany, highlighted a statistically significant increase in mortality for other than lung cancers (stomach and liver), but not for brain and CNS $[43,58]$. Finally, in the Colorado Plateau cohort (3358 white miners and 779 miners of another race) a significant risk to develop some cancer types was found but not brain or CNS cancers [44]. 


\subsubsection{General Population}

In 1993, Hess et al. demonstrated significant correlation between Rn levels throughout the countries of the state of Maine, USA, and incidence of all cancers, including brain and nervous system cancer [59]. Similarly, twenty years later, a Danish study in a cohort of 57,053 persons observed a statistically significant association between residential $\mathrm{Rn}$ and brain cancers. The adjusted incidence rate-ratios (IRR) for primary brain tumor associated with each $100 \mathrm{~Bq} / \mathrm{m}^{3}$ increment in average residential Rn levels was 1.96 (95\% CI: 1.07-3.58). This association was not modified by air pollution [47]. Later, a paper from a Spanish group observed a significant correlation between residential Rn exposure and brain cancer mortality, with a higher correlation for females. These results were reinforced when the analysis was restricted to municipalities with more than five Rn measurements, showing Spearman's Rho equal to 0.286 ( $p$-value $<0.001)$ and 0.509 ( $p$-value $<0.001)$ for males and females, respectively [48]. Again, another Spanish study highlighted that indoor Rn concentration in Galicia was statistically associated with higher lung, stomach, and brain cancer mortality only among women [49].

In contrast, Monastero et al. reported no relationship between mean Rn levels and CNS cancer incidence in five highly populated and Rn-enriched US states [50], as well as the Turner's study performed in the American Cancer Society cohort [46].

\subsubsection{Pediatric Population}

In 1991, the association between groundwater Rn levels and childhood cancer mortality in North Carolina was explored. This study highlighted an increase of the relative risks for several cancers, included brain and CNS tumors [51]. Another study considered children suffering from leukemia and common solid tumors (nephroblastoma, neuroblastoma, rhabdomyosarcoma, and CNS tumors) diagnosed between 1988 and 1993 in Lower Saxony, Germany. Rn measurements were performed for one year in those homes where the children had been living for at least one year, with particular attention posed to those rooms where they had stayed most of the time. The risk estimates were high for solid tumors (OR: 2.61; 95\% CI: 0.96-7.13) [52].

In contrast with these results, in a Danish children cohort, the cumulative Rn exposure was not associated with risk for CNS tumor [53], as well as in a Swiss study where a cohort of 997 childhood cancer cases was evaluated. Specifically, compared with children exposed to Rn concentration below the median $\left(<77.7 \mathrm{~Bq} / \mathrm{m}^{3}\right)$, adjusted hazard ratios for children with exposure $\geq$ the 90 th percentile $\left(\geq 139.9 \mathrm{~Bq} / \mathrm{m}^{3}\right)$ were $0.93(95 \%$ CI: $0.74-1.16)$ for all cancers and 1.05 (95\% CI: 0.68-1.61) for CNS tumors [54]. Similarly, Kendal et al. reported how Rn exposure was not significant for brain and CNS childhood cancers in children born and diagnosed with cancer or nonmalignant brain tumor in Great Britain between 1980 and 2006, as recorded on the National Registry of Childhood Tumors [55]. Again, in a Norway cohort of 712,674 children with a total of 864 cancer cases 427 of them related to the CNS, an elevated non-significant risk for cancer was observed [56]. An ecological study related to a cohort of 5471 children with CNS tumors demonstrated that there was no association between Rn exposure and childhood CNS tumors incidence (IRR: 1.07; CI: 0.95-1.20 per $100 \mathrm{~Bq} / \mathrm{m}^{3}$ ) [57]. Finally, the results of a review performed on 18 studies ( 8 on miners, 3 on the general population, and 7 on children) are inconclusive because the available studies are extremely heterogeneous in terms of design and populations [60].

\subsection{Leukemia}

The main results are described in Table 2a (Workers) and Table 2b (General and Pediatric Population).

\subsubsection{Workers}

A report of Tomasek et al. demonstrated an increased mortality trend from multiple myeloma with cumulative exposure to $\mathrm{Rn}$ and an increasing trend of leukemia mortality with long-lasting employment in uranium mines. Mortality from multiple myeloma, 
although not significantly increased overall, increased with cumulative exposure to Rn. Instead, mortality from leukemia was not increased overall and was not related to cumulative Rn exposure but did increase with increasing duration of employment in the mines [61]. In a pooled statistical analysis combining 11 epidemiological studies on underground uranium miners, Darby et al. established increased leukemia mortality only in the period of less than 10 years after beginning work at mine [40]. In a case-cohort study in Czech uranium miners, exposure to Rn and its progeny was associated with an increased risk of developing leukemia. Particularly, an increased incidence of all types of leukemia, along with chronic lymphocytic leukemia, in relation to cumulative Rn exposure has been observed. The relative risk (RR) comparing high Rn exposure (110 WLM; 80th percentile) to lower Rn exposure (3 WLM; 20th percentile) was equal to 1.75 (95\% CI: 1.10-2.78; $p$-value $=0.014)$ for all leukemia subtypes combined and 1.98 (95\% CI: 1.10-3.59; $p$-value $=0.016)$ for chronic lymphocytic leukemia (CLL) [62].

Table 2. Radon exposure and leukemia.

\begin{tabular}{|c|c|c|c|c|}
\hline \multicolumn{5}{|c|}{ a: Workers } \\
\hline $\begin{array}{c}\text { Study } \\
\text { Design }\end{array}$ & $\begin{array}{l}\text { Sample Size } \\
(n)\end{array}$ & $\begin{array}{l}\text { Radon } \\
\text { Conc. }\end{array}$ & Results & $\begin{array}{l}\text { Reference } \\
\text { (Year) }\end{array}$ \\
\hline $\begin{array}{l}\text { Cohort mortality } \\
\text { study }\end{array}$ & 4320 & 196.8 WLM ${ }^{1}$ & $\begin{array}{l}\text { O/E deaths: } 1.11 ; 95 \% \text { CI: } 0.98-1.24 \\
\text { No significant association }\end{array}$ & $\begin{array}{l}\text { Tomàsek et al. } \\
\text { (1993) [61] }\end{array}$ \\
\hline Cohort study & 64,209 & 155 WLM $^{1}$ & $\begin{array}{l}\text { O/E: } 1.93 ; 95 \% \text { CI: } 1.19-2.95 \\
\text { No significant association }\end{array}$ & $\begin{array}{l}\text { Darby et al. } \\
(1995)[40]\end{array}$ \\
\hline $\begin{array}{l}\text { Retrospective } \\
\text { case-cohort study }\end{array}$ & 23,043 & $\begin{array}{c}\text { mean } \pm \text { sd: } \\
64.1 \pm 98 \mathrm{WLM}\end{array}$ & $\begin{array}{c}\text { All leukemia } \\
\text { RR: 1.75; 95\% CI: } 1.10-2.78 ; \\
p \text {-value }=0.014 \\
\text { CLL } \\
\text { RR: n.s. }\end{array}$ & $\begin{array}{l}\text { Rericha et al. } \\
\text { (2006) [62] }\end{array}$ \\
\hline Cohort study & 58,987 & 279.4 WLM & $\begin{array}{l}\text { No significant association } \\
\text { O/E: } 0.89 ; 95 \% \text { CI: 0.74-1.06 }\end{array}$ & $\begin{array}{l}\text { Kreuzer et al. } \\
(2008)[43]\end{array}$ \\
\hline Cohort study & 17,660 & 100.2 WLM & $\begin{array}{c}\text { All leukemia } \\
\text { SMR: } 0.69 ; 95 \% \text { CI: } 0.48-0.97 \\
p \text {-value }=0.031 \\
\text { SIR: } 0.79 ; 95 \% \text { CI: } 0.59-1.03 \\
p \text {-value }=0.088\end{array}$ & $\begin{array}{l}\text { Zablotska et al. } \\
\text { (2014) [63] }\end{array}$ \\
\hline Cohort study & 16,434 & 53 WLM & $\begin{array}{c}\text { All leukemias: } \\
\text { SIR: } 1.51 ; 95 \% \text { CI: } 1.08-2.07 \\
\text { Lymphatic and hematopoietic cancers } \\
\text { combined } \\
\text { SIR: } 1.31 ; 95 \% \text { CI: } 1.05-1.61\end{array}$ & $\begin{array}{l}\text { Kelly-Reif et al. } \\
\text { (2019) [64] }\end{array}$ \\
\hline \multicolumn{5}{|c|}{ b: General and Pediatric Population } \\
\hline $\begin{array}{l}\text { Study } \\
\text { Design }\end{array}$ & $\begin{array}{l}\text { Sample Size } \\
(n)\end{array}$ & $\begin{array}{l}\text { Radon } \\
\text { Conc. }\end{array}$ & Results & $\begin{array}{l}\text { Reference } \\
\text { (Year) }\end{array}$ \\
\hline Ecological study & 45 & $<120 \mathrm{~Bq} / \mathrm{m}^{3}$ & $\begin{array}{c}\text { Lymphocytic leukemia } \\
\mathrm{r}=0.40 ; p \text {-value }<0.005 \\
\rho=0.24 ; p \text {-value }<0.1 \\
\text { Myeloid leukemia } \\
\mathrm{r}=0.43 ; p \text {-value }<0.005 \\
\rho=0.22 p \text {-value }<01\end{array}$ & $\begin{array}{l}\text { Eatough et al. } \\
\text { (1993) [65] }\end{array}$ \\
\hline Ecological study & $\begin{array}{l}\text { Area } \geq 100 \mathrm{~Bq} / \mathrm{m}^{3} \\
\text { Cases: } 35 \\
\text { Area }<100 \mathrm{~Bq} / \mathrm{m}^{3} \\
\text { Cases: } 73\end{array}$ & $\begin{array}{l}\text { Area } \geq 100 \mathrm{~Bq} / \mathrm{m}^{3} \\
\left(\text { Mean: } 183 \mathrm{~Bq} / \mathrm{m}^{3}\right) \\
\text { Area }<100 \mathrm{~Bq} / \mathrm{m}^{3} \\
\left(\text { Mean: } 57 \mathrm{~Bq} / \mathrm{m}^{3}\right)\end{array}$ & $\begin{array}{c}\text { Area } \geq 100 \mathrm{~Bq} / \mathrm{m}^{3}: \\
\text { Incidence }=106.7 \text { per million child } \\
\text { years } \\
\text { Area }<100 \mathrm{~Bq} / \mathrm{m}^{3}: \text { Incidence }=121.7 \\
\text { per million child years } \\
\text { No significant difference between } \\
\text { Area } \geq 100 \mathrm{~Bq} / \mathrm{m}^{3} \text { and Area }<100 \\
\mathrm{~Bq} / \mathrm{m}^{3}(p \text {-value }=0.29) .\end{array}$ & $\begin{array}{l}\text { Thorne et al. } \\
\text { (1996) [66] }\end{array}$ \\
\hline
\end{tabular}


Table 2. Cont.

\begin{tabular}{|c|c|c|c|c|}
\hline \multicolumn{5}{|c|}{ b: General and Pediatric Population } \\
\hline $\begin{array}{l}\text { Study } \\
\text { Design }\end{array}$ & $\begin{array}{c}\text { Sample Size } \\
(n)\end{array}$ & $\begin{array}{l}\text { Radon } \\
\text { Conc. }\end{array}$ & Results & $\begin{array}{l}\text { Reference } \\
\text { (Year) }\end{array}$ \\
\hline Case-control study & $\begin{array}{l}\text { Cases: } 173 \\
\text { Controls: } 254\end{array}$ & $\begin{array}{c}{ }^{1} \text { Cases: } 56.0 \mathrm{~Bq} / \mathrm{m}^{3} \\
{ }^{1} \text { Controls: } 49.8 \\
\mathrm{~Bq} / \mathrm{m}^{3}\end{array}$ & $\begin{array}{l}\quad 37-100 \mathrm{~Bq} / \mathrm{m}^{3} \\
\text { adjusted OR: } 1.2 ; 95 \% \text { CI: } 0.7-1.8 \\
>100 \mathrm{~Bq} / \mathrm{m}^{3} \\
\text { adjusted OR: } 1.1 ; 95 \% \text { CI } 0.6-2.0 \\
\text { No significant difference }\end{array}$ & $\begin{array}{l}\text { Steinbuch et al. } \\
\text { (1999) [67] }\end{array}$ \\
\hline Case-control study & $\begin{array}{l}\text { Cases: } 505 \\
\text { Controls: } 443\end{array}$ & $\begin{array}{c}{ }^{1} \text { Cases } \\
65.4 \mathrm{~Bq} / \mathrm{m}^{3} \\
{ }^{1} \text { Controls } \\
79.1 \mathrm{~Bq} / \mathrm{m}^{3}\end{array}$ & $\begin{array}{c}\text { Rn concentration }<37 \mathrm{~Bq} / \mathrm{m}^{3} \\
\text { RR: } 1 \text {; (Reference) } \\
\text { Rn concentration } 37-73 \mathrm{~Bq} / \mathrm{m}^{3} \\
\text { RR: } 1.22 ; 95 \% \text { CI: } 0.8-1.9 \\
\text { Rn concentration } 74-147 \mathrm{~Bq} / \mathrm{m}^{3} \\
\text { RR: } 0.82 ; 95 \% \text { CI: } 0.8-1.9 \\
\text { Rn concentration } \geq 148 \mathrm{~Bq} / \mathrm{m}^{3} \\
\text { RR: } 1.02 ; 95 \% \text { CI: } 0.5-2.0\end{array}$ & $\begin{array}{l}\text { Lubin et al. } \\
\text { (1998) [68] }\end{array}$ \\
\hline Case-control study & $\begin{array}{c}\text { Cases: } 82 \\
\text { Controls: } 209\end{array}$ & $\begin{array}{c}\text { Median: } \\
27 \mathrm{~Bq} / \mathrm{m}^{3} \\
\text { Range: } \\
10-584 \mathrm{~Bq} / \mathrm{m}^{3}\end{array}$ & OR: $1.30 ; 95 \%$ CI: $0.32-5.33$ & $\begin{array}{l}\text { Kaletsch et al. } \\
\text { (1999) [52] }\end{array}$ \\
\hline Case-control study & $\begin{array}{l}\text { Cases: } 3838 \text { cases } \\
(1461 \text { ALL }) \\
\text { Controls } 7629\end{array}$ & ${ }^{1} 24.0 \mathrm{~Bq} / \mathrm{m}^{3}$ & OR: $0.80 ; 95 \%$ CI: $0.64-0.99$ & $\begin{array}{l}\text { UKCCS [69] } \\
\quad(2002)\end{array}$ \\
\hline Ecological study & Data not provided & $\begin{array}{c}\text { UK: } 20 \mathrm{~Bq} / \mathrm{m}^{3} \text {; } \\
\text { Cornwall: } 110 \\
\text { Bq/m } \\
\text { World: } 50 \mathrm{~Bq} / \mathrm{m}^{3}\end{array}$ & $\begin{array}{l}\text { Country data alone } \\
\mathrm{r}=0.65 ; p \text {-value }<0.02 \\
\quad \text { Regional data } \\
\mathrm{r}=0.62 ; p \text {-value }<0.02\end{array}$ & $\begin{array}{l}\text { Henshaw et al. } \\
\text { (1990) [70] }\end{array}$ \\
\hline Ecological study & $\begin{array}{l}\text { Leukemias and } \\
\text { lymphomas: } 4851\end{array}$ & median: $21 \mathrm{~Bq} / \mathrm{m}^{3}$, & RR: 1.06; 95\% CI: 0.99-1.12 & $\begin{array}{l}\text { Gilman et al. } \\
\text { (1998) [71] }\end{array}$ \\
\hline $\begin{array}{c}\text { Ecological } \\
\text { correlation study }\end{array}$ & 53,146 & $\begin{array}{c}\text { High risk area: } \\
50,000 \mathrm{~Bq} / \mathrm{m}^{3} ; \\
\text { Normal risk area: } \\
10,000-50,000 \\
\mathrm{~Bq} / \mathrm{m}^{3} ; \\
\text { Low risk area: } \\
<10,000 \mathrm{~Bq} / \mathrm{m}^{3} \text {; }\end{array}$ & $\begin{array}{c}\text { ALL }^{2}: \\
\text { RR (normal risk area): } 4.64 \\
\text { 95\% CI: } 1.29-28.26 \\
\text { RR (high risk area): } 5.67 \\
\text { 95\% CI: } 1.06-42.27\end{array}$ & $\begin{array}{l}\text { Kohli et al. } \\
\text { (2000) [72] }\end{array}$ \\
\hline Cohort study & $\begin{array}{l}\text { Childhood cancer } \\
\text { cases: } 997\end{array}$ & $\begin{array}{c}77.7^{1} \mathrm{~Bq} / \mathrm{m}^{3}, 90 \mathrm{th}: \\
139.9 \mathrm{~Bq} / \mathrm{m}^{3}\end{array}$ & $\begin{array}{c}\text { All leukemias } \\
\text { AHR: 0.90; 95\% CI: 0.56-1.43 } \\
\text { Acute lymphoblastic leukemia } \\
\text { AHR: } 0.90 ; 95 \% \text { CI: } 0.56-1.43\end{array}$ & $\begin{array}{l}\text { Hauri D et al. } \\
\text { (2013) [54] }\end{array}$ \\
\hline
\end{tabular}

a: ${ }^{1}$ Average cumulative exposure; ${ }^{2}$ lifetime Rn exposure. WLM: Working Level Month; O/E: observed/expected cases; $95 \%$ CI: 95\% confidence interval; RR: Relative Risk; CLL: chronic lymphocytic leukemia; ALL = acute lymphatic leukemia; AML: acute myeloid leukemia; n.s.: not significant. b: ${ }^{1}$ Arithmetic mean of time-weighted radon concentrations; ${ }^{2}$ ALL: acute lymphatic leukemia; RR: Relative Risk; $95 \%$ CI: $95 \%$ confidence interval; OR: odds ratio; r: correlation coefficient; AHR: Adjusted Hazard Ratio.

Kreuzer et al. analyzed a cohort including 58,987 men employed for at least 6 months from 1946 to 1989 at the former Wismut uranium mining company in Eastern Germany. The number of deaths observed for leukemia was close to that expected from national rates. No association between cumulative Rn exposure and leukemia was found, or with chronic lymphatic leukemia (CLL), non-CLL or acute myeloid leukemia (AML) [43].

Zabloska et al. analyzed radiation-related risks of hematologic cancers in the cohort of Eldorado uranium miners and processors first employed in 1932-1980 in relation to cumulative Rn decay products (RDP) exposures and $\gamma$-ray doses. The average cumulative RDP exposure was 100.2 working level months (WLM). No statistically significant associ- 
ation between RDP exposure or $\gamma$-ray doses, or a combination of both, and mortality or incidence of any hematologic cancer was found [63].

A cohort of 16,434 male underground miners from Czech Republic were exposed to low and moderate levels of Rn gas and other hazards. The SIR was elevated for all leukemias (SIR: 1.51; 95\% CI: 1.08-2.07) and for lymphatic and hematopoietic cancers combined (SIR: $1.31 ; 95 \%$ CI: 1.05-1.61) [64].

\subsubsection{General Population}

With regard to environmental exposure, in 1989 Lucie suggested a relationship between Rn concentration and the incidence of leukemia in England and Wales [73]. Subsequently, significant correlations between Rn concentration and several leukemia subtypes in England and Wales have been observed [74]. Similarly, Eatough et al. observed a significant correlation between standardized registration ratio (SRR) for monocytic leukemia and the Rn concentration by county in England. The authors showed these results had been unlikely produced by regional variations in registration efficiency or by being confounded due to social class or to gamma radiation exposure [65]. In line with these data, Henshaw et al., suggested that for the world average Rn exposure of $50 \mathrm{~Bq} / \mathrm{m}^{3}, 13-25 \%$ of myeloid leukemia at all ages might be caused by $\mathrm{Rn}[70]$.

\subsubsection{Pediatric Population}

Between 1976 and 1985 in Britain, Thorne and colleagues evaluated the incidence of childhood malignancies compared to postcode sectors with a Rn exposure $\geq 100 \mathrm{~Bq} / \mathrm{m}^{3}$ with sectors with a $\mathrm{Rn}$ exposure $<100 \mathrm{~Bq} / \mathrm{m}^{3}$. No significant difference in the incidence rate as compared to all cancers and no association between Rn exposure and overall rate of childhood malignancy were found [66]. Steinbuch et al. evaluated the risk factors for childhood acute myeloid leukemia associated with indoor residential Rn level within a larger interview-based case-control study performed over 120 institutions in the USA and Canada. A total of 173 cases and 254 controls were analyzed and no association was observed between Rn exposure and risk of acute myeloid leukemia, with adjusted OR of $1.2(95 \%$ CI $0.7-1.8)$ for $37-100 \mathrm{~Bq} / \mathrm{m}^{3}$ and 1.1 (95\% CI: 0.6-2.0) for $>100 \mathrm{~Bq} / \mathrm{m}^{3}$ compared with $<37 \mathrm{~Bq} / \mathrm{m}^{3}$ [67]. In another study, including 505 cases and 443 age matched controls, the association between the incidence of acute lymphatic leukemia (ALL) in children under age 15 years and indoor Rn exposure was investigated. Mean radon concentration was lower for case subjects $\left(65.4 \mathrm{~Bq} / \mathrm{m}^{3}\right)$ than for control subjects $\left(79.1 \mathrm{~Bq} / \mathrm{m}^{3}\right)$. Therefore, the results from this analytic study provide no evidence for an association between indoor $\mathrm{Rn}$ exposure and childhood ALL [68].

Kaletsch et al. conducted a case/control study on 82 cases of childhood leukemia in Lower Saxony. Long term Rn measurements were carried out in dwellings where the children had lived for at least one year. There was no association between higher radon levels and leukemia [OR: 1.30; 95\% CI: 0.32-5.33)] [52].

One of the largest of the available case/control studies was conducted in the United Kingdom. The parents of 3838 children with cancer (1461 of which were of acute lymphoblastic leukemia) and of 7629 children without cancer were interviewed. The arithmetic mean $\mathrm{Rn}$ concentration measured in the homes was $24.0 \mathrm{~Bq} / \mathrm{m}^{3}$, with the mean concentration being slightly lower in case homes than in control homes. No evidence to support an association between higher Rn concentrations and risk of any of the childhood cancers was then found [69].

In contrast, the analysis performed by Henshaw et al. for myeloid leukemia in UK children suggested that the $6-12 \%$ incidence might be attributed to Rn exposure, the figure becoming $23-43 \%$ in Cornwall, where Rn levels are higher [70]. In the same way, for data from throughout Britain, a significant correlation for childhood leukemia with Rn concentration by county was observed [75]. Gilman and Knox conducted a study about 8500 cases of childhood cancers diagnosed up to age 15 and born in Great Britain between 1953 and 1964. There was a significant positive trend of mortality with increasing 
Rn exposure for leukemias and lymphomas (RR. 1.06, CI 0.99-1.12), just failing to reach statistical significance [71].

In 2000, a Swedish study assessed 53,146 children, and among these, 90 developed hematologic malignancies. Standardized mortality ratios (SMR) for acute lymphatic leukemia among children born in high, normal, and low risk areas were 1.43, 1.17, and 0.25 , respectively. The RR for normal risk group and high-risk group as compared with the low-risk group was 4.64 (95\% CI: 1.29-28.26) and 5.67 (95\% CI: 1.06-42.27). The association between acute lymphatic leukemia and continued residence in normal or high-risk areas showed a similar trend. No association between Rn risk levels and any other malignancy was seen. This study evidenced that children born in and continuously living in areas classified as high and normal risk for background radiation of Rn have a higher incidence of acute lymphatic leukemia [72]. Later in 2012, a meta-analysis of case-control studies was conducted to uncover the influence of Rn exposure on childhood leukemia. The combined OR for calculating the lowest exposure of Rn on the high incidence of childhood leukemia was 1.37 (95\% CI: 1.02-1.82), suggesting a weak association. A major source of uncertainty was the Rn dose estimate [76]. However, in a 2016 review about environmental exposure and risk of childhood leukemia, Schüz concluded that radiation is not a contributor to the global childhood leukemia burden [77].

\subsection{Skin Cancer}

As regards Rn exposure and skin cancer, scientific works are mainly focused on the general population (See Table 3).

Table 3. Skin cancer: General Population.

\begin{tabular}{|c|c|c|c|c|}
\hline $\begin{array}{l}\text { Study } \\
\text { Design }\end{array}$ & $\begin{array}{c}\text { Sample Size } \\
(n)\end{array}$ & $\begin{array}{l}\text { Radon } \\
\text { Conc. }\end{array}$ & Results & $\begin{array}{l}\text { Reference } \\
\text { (Year) }\end{array}$ \\
\hline Ecological study & 28,989 & $\begin{array}{l}140 \mathrm{~Bq} / \mathrm{m}^{3} \\
1 \geq 230 \mathrm{~Bq} / \mathrm{m}^{3}\end{array}$ & $\begin{array}{l}\text { Non-melanoma skin cancers, showed a } \\
\text { significant increase in incidence in the } \\
\text { high-radon postcode sectors }(\geq 100 \\
\left.\mathrm{Bq} / \mathrm{m}^{3}\right) \text { compared with the low-radon } \\
\text { sectors }\left(<60 \mathrm{~Bq} / \mathrm{m}^{3}\right) \text { and this effect was } \\
\text { observed for both sexes. }\end{array}$ & $\begin{array}{l}\text { Etherington et al. } \\
\text { (1996) [78] }\end{array}$ \\
\hline Prospective study & 811,961 & $\begin{array}{c}\text { mean } \pm \text { sd: } \\
53.5 \pm 38.0 \mathrm{~Bq} / \mathrm{m}^{3} \\
\text { range: } \\
6.3-265.7 \mathrm{~Bq} / \mathrm{m}^{3}\end{array}$ & $\begin{aligned} & \mathrm{HR}= 0.98 ; 95 \% \mathrm{CI}: 0.97-1.00, \text { per each } \\
& 100 \mathrm{~Bq} / \mathrm{m}^{3} \\
& \text { no significant association }\end{aligned}$ & $\begin{array}{l}\text { Turner et al. } \\
\text { (2012) [46] }\end{array}$ \\
\hline Ecological study & 18,350 & $\begin{array}{c}\text { mean } \pm \text { sd: } \\
98.1 \pm 73.1 \mathrm{~Bq} / \mathrm{m}^{3}\end{array}$ & $\begin{array}{c}\text { Malignant melanoma } \\
\text { Rn concentration } \geq 230 \mathrm{~Bq} / \mathrm{m}^{3} \\
\text { RR: } 0.85 ; 95 \% \text { CI: } 0.65-1.11 \\
\text { Basal cell carcinoma } \\
\text { Rn concentration } \geq 230 \mathrm{~Bq} / \mathrm{m}^{3} \\
\text { RR: } 0.81 ; 95 \% \text { CI: } 0.66-1.00 \\
\text { Squamous cell carcinoma } \\
\text { Rn concentration } \geq 230 \mathrm{~Bq} / \mathrm{m}^{3} \\
\text { RR: } 1.76 ; 95 \% \mathrm{CI}: 1.46-2.11\end{array}$ & $\begin{array}{l}\text { Wheeler et al. } \\
\text { (2012) [79] }\end{array}$ \\
\hline Ecological study & 206,454 & $\begin{array}{c}\text { range: } \\
0-\geq 100 \mathrm{~Bq} / \mathrm{m}^{3}\end{array}$ & $\begin{array}{c}0.18^{2} \text { registrations } \\
\text { per } 100,000 \text { population per year } \\
95 \% \text { CI: } 0.04-0.32 p \text {-value }=0.011\end{array}$ & $\begin{array}{l}\text { Wheeler et al. } \\
\text { (2013) [80] }\end{array}$ \\
\hline Prospectic cohort & 57,053 & $\begin{array}{c}\text { median: } 38.3 \\
\mathrm{~Bq} / \mathrm{m}^{3}\end{array}$ & $\begin{array}{c}\text { BCC } \\
\text { Adjusted IRR: 1.14; } \\
\text { 95\% CI: } 1.03-1.27 \\
\text { SCC } \\
\text { Adjusted IRR: 0.90; } 95 \% \text { CI: } 0.70-1.37 \\
\text { MM } \\
\text { Adjusted IRR: } 1.08 ; 95 \% \text { CI: } 0.77-1.50\end{array}$ & $\begin{array}{l}\text { Bräuner et al. } \\
\text { (2015) [81] }\end{array}$ \\
\hline
\end{tabular}


Table 3. Cont

\begin{tabular}{|c|c|c|c|c|}
\hline $\begin{array}{l}\text { Study } \\
\text { Design }\end{array}$ & $\begin{array}{c}\text { Sample Size } \\
(n)\end{array}$ & $\begin{array}{l}\text { Radon } \\
\text { Conc. }\end{array}$ & Results & $\begin{array}{l}\text { Reference } \\
\text { (Year) }\end{array}$ \\
\hline Ecological study & 2294 & $\begin{array}{l}\text { Cutpoint set: } \\
50 \mathrm{~Bq} / \mathrm{m}^{3}\end{array}$ & $\begin{array}{c}\text { Risk of non-pulmonary cancer } \\
\text { HR: } 1.2 ; 95 \% \text { CI: } 0.9-1.6 \\
\text { Connective tissue and others of the skin } \\
\text { HR: } 1.5 ; 95 \% \text { CI: } 0.6-3.8 \\
\text { (except melanoma) }\end{array}$ & $\begin{array}{c}\text { Barbosa-Lorenzo } \\
\text { et al. } \\
\text { (2016) [82] }\end{array}$ \\
\hline Mortality cohorts & $\begin{array}{c}\text { Tot: 5,249,462 skin } \\
\text { cancer deaths: } \\
2989\end{array}$ & $\begin{array}{c}\text { mean } \pm \text { sd: } 91.8 \pm \\
47.8 \mathrm{~Bq} / \mathrm{m}^{3}\end{array}$ & $\begin{array}{c}\mathrm{MM} \\
\mathrm{HR}^{3}: 1.41 ; 95 \% \text { CI: } 1.09-1.80 \text { at } 30 \text { years } \\
\mathrm{HR}^{3}: 1.05 ; 0.94-1.18 \text { at } 75 \text { years } \\
\text { Adjusted HR: } 1.16 ; 95 \% \text { CI: } 1.04-1.29 \text { at } \\
60 \text { years }\end{array}$ & $\begin{array}{l}\text { Vienneau et al. } \\
\text { (2017) [83] }\end{array}$ \\
\hline
\end{tabular}

${ }^{1}$ Average radon levels for postcode sectors; ${ }^{2}$ adjusted coefficient per $1 \mathrm{~Bq} / \mathrm{m}^{3}$ increase; ${ }^{3}$ per $100 \mathrm{~Bq} / \mathrm{m}^{3} ; 95 \%$ CI: $95 \%$ confidence interval; sd: standard deviation; IRR: incidence rate-ratios; HR: Hazard Ratio. BCC: basal cell carcinoma; SCC: squamous cell carcinoma; MM: malignant melanoma.

\section{General Population}

The American Cancer Prevention Study II (CPS-II), a large prospective study of nearly 1.2 million participants recruited in 1982 by the American Cancer Society, highlighted no association between residential Rn and any other mortality cause beyond lung cancer or chronic obstructive pulmonary disease. With regard to the relationship with skin cancer, the authors calculated HRs of 1.08 (95\% CI: 0.88-1.33) and 0.70 (95\% CI: 0.42-1.19) per $100 \mathrm{~Bq} / \mathrm{m}^{3}$ in mean county-level residential $\mathrm{Rn}$ for malignant melanoma and nonmelanoma skin cancer mortality, respectively [46]. In 1996, Etherington et al., studying the relationship between domestic Rn levels and cancer in southwest England, observed that only non-melanoma skin cancers showed a significant increase in incidence in the high-Rn sectors $\left(\geq 100 \mathrm{~Bq} / \mathrm{m}^{3}\right)$ compared to the low-Rn sectors $\left(<60 \mathrm{~Bq} / \mathrm{m}^{3}\right)$ [78]. Later, still in the southwest of England, the ecological epidemiology data provided no evidence for elevated skin cancer risks at $\mathrm{Rn}$ levels $<100 \mathrm{~Bq} / \mathrm{m}^{3}$ [84]. Wheeler et al. found an association between Rn levels in Southwest England and incidence of squamous cell carcinoma (SCC), but not for basal cell carcinoma (BCC) or malignant melanoma [79]. The same authors did not find an association with incidence of non-melanoma skin cancer (SCC and BCC combined) [80]. In a cohort study in Galicia performed on 2294 subjects, no association appeared for several tumors except for melanoma [82]. In a Danish cohort, Bräuner et al. found a statistically significant association between basal cell carcinoma and Rn (IRR: 1.14; 95\% CI: 1.03-1.27) but not for squamous cell carcinoma (IRR: 0.90 ; 95\% CI 0.70-1.37) and malignant melanoma (IRR: 1.08; 95\% CI: 0.77-1.50) [81]. In contrast, in a study conducted in Switzerland, a significant positive association with malignant melanoma mortality and Rn exposure was observed with an HR of 1.16 (95\% CI: 1.04-1.29) per 100 Bq/m³ [83]. Finally, Denman et al., considering the Rn levels in abandoned mines and the lung and skin dose received by visitors, highlighted the increased lifetime risk of skin cancer due to a $1 \mathrm{~h}$ exposure in each mine. The results indicated that if visitors ensure that their $\mathrm{Rn}$ exposure is below the National Radiological Protection Board (NRPB) guideline of $106 \mathrm{~Bq} / \mathrm{m}^{3} \mathrm{~h}$ in 1 year, the skin dose and effective dose will both be below the annual limits for UK radiation workers and below the levels at which any acute skin effect will occur [85].

\subsection{Stomach Cancer}

Table 4 summarized the main results related to workers and general population.

\subsubsection{Workers}

Deaths from several cancer types, including stomach tumor, are elevated among the miners. In a collaborative analysis of data from 11 cohorts of underground miners in which Rn-related excesses of lung cancer had been established, Darby et al. examined the mortality from non-lung cancer. The study included 64,209 men who were employed in 
the mines for 6.4 years on average. Among 28 individual cancer categories, statistically significant increases in mortality for cancers of the stomach (O/E: 1.33; 95\% CI: 1.16-1.52) were observed [40]. Similarly, a cohort of underground miners in the Czech Republic between 1977 and 1992 was selected from the registry Příbram Uranium Industry (UI) employees. There was a $52 \%$ increase in deaths from all malignant causes compared with expected rates (SMR: 1.52, 95\% CI: 1.44-1.60). In addition to lung cancer, mortality was also higher for other cancer subtypes, particularly stomach cancer (SMR: 1.27; 95\% CI: 1.02-1.51), as well as all cancer incidence, stomach cancer included (SIR: 1.37; 95\% CI: 1.11-1.63) [64]. In Swedish iron miners occupationally exposed to elevated levels of the radioactive gas $\mathrm{Rn}$, mortality was increased for all cancers other than lung cancer. With regard to stomach cancer, ratio of observed to expected deaths was 1.45 , with a $95 \%$ C.I. of 1.04-1.98. However, the authors underlined that the increase in stomach cancer mortality might be due to the considerable number of Finns in the workforce, in which stomach cancer rates were considerably higher than in Swedish population. In addition, mortality was not significantly associated with cumulative Rn exposure [41]. Finally, in a cohort of 28,546 workers in Ontario uranium mines, no association was observed between increasing cumulative Rn exposure and other than lung cancer (e.g., stomach, leukemia, kidney, and extrathoracic airways) [86].

Table 4. Stomach cancer: Workers and General Population.

\begin{tabular}{|c|c|c|c|c|}
\hline $\begin{array}{l}\text { Study } \\
\text { Design }\end{array}$ & $\begin{array}{l}\text { Sample Size } \\
(n)\end{array}$ & $\begin{array}{l}\text { Radon } \\
\text { Conc. }\end{array}$ & Results & $\begin{array}{l}\text { Reference } \\
\text { (Year) }\end{array}$ \\
\hline Cohort study & 64,209 & 155 WLM & $\begin{array}{l}\text { O/E: } 1.33 ; 95 \% \text { CI: } 1.169-1.52 \\
\text { Mortality: no significant association }\end{array}$ & $\begin{array}{l}\text { Darby et al. } \\
(1995) \text { [40] }\end{array}$ \\
\hline Cohort study & 1415 & 89 WLM & $\begin{array}{l}\text { O/E: } 1.45 ; 95 \% \text { CI: } 1.04-1.98 \\
\text { Mortality: no significant association }\end{array}$ & $\begin{array}{l}\text { Darby et al. } \\
(1995)[41]\end{array}$ \\
\hline Cohort study & 28,546 & 21 WLM & $\begin{array}{c}\text { Incidence: Overall excess }{ }^{1} \\
\text { RR: }-0.12 ; 95 \% \text { CI: }-0.59-0.35 \\
\text { Mortality: overall excess }{ }^{1} \\
\text { RR: }-0.082 ; 95 \% \text { CI: }-0.61-0.45 \\
\text { No significant association }\end{array}$ & $\begin{array}{l}\text { Navaranjan et al. } \\
\quad \text { (2016) [86] }\end{array}$ \\
\hline Ecological study & 5218 & $\begin{array}{l}\text { Groundwater: } 100 \\
\text { Bq/L Indoor air: } \\
100 \mathrm{~Bq} / \mathrm{m}^{3}\end{array}$ & $\begin{array}{c}\text { Groundwater Rn exposure and } \\
\text { stomach cancer } \\
\text { OR: } 1.24 ; 95 \% \text { CI } 1.03-1.49\end{array}$ & $\begin{array}{l}\text { Messier et al. } \\
\text { (2017) [87] }\end{array}$ \\
\hline Ecological study & 56,385 & $\begin{array}{c}\text { IQ range: } \\
53-184 \mathrm{~Bq} / \mathrm{m}^{3}\end{array}$ & $\begin{array}{l}\text { Statistical association in women } \\
\text { RR: } 1.17 ; 95 \% \text { CI 1.02-1.32 }\end{array}$ & $\begin{array}{l}\text { López-Abente et al. } \\
\text { (2018) [49] }\end{array}$ \\
\hline Cohort study & 16,434 & 53 WLM & $\begin{array}{c}\text { SMR: } 1.27 ; 95 \% \text { CI: } 1.02-1.51 \\
\text { SIR: } 1.37 ; 95 \% \text { CI: } 1.11-1.63\end{array}$ & $\begin{array}{l}\text { Kelly-Reif et al. } \\
\text { (2019) [64] }\end{array}$ \\
\hline
\end{tabular}

${ }^{1}$ Per 100 WLM; WML: Working Level Month; 95\% CI: 95\% confidence interval; O/E: observed/expected cases; SMR: Standardized Mortality Ratio; SIR: Standardized Incidence Ratio; RR: relative risk; IQ: interquartile range; OR: Odd ratio.

\subsubsection{General Population}

In a retrospective analysis that compared Rn levels for each county in Pennsylvania to the incidence and mortality of gastrointestinal cancer, a positive correlation was found for stomach cancer in females, and the mortality of stomach cancer for male, female, and total population [88]. Messier et al. provided epidemiological evidence of a positive association between groundwater Rn concentration and an increase in the probability of a stomach cancer [87]. Moreover, Lopez-Abente evaluated the cancer mortality in Galicia and residential Rn levels. For the whole study period (1999-2008), mortality data for each of the 313 Galician municipalities were drawn from the records of the National Statistics Institute. Expected cases were computed using Galician mortality rates for 14 types of malignant tumors as reference, with a total of 56,385 deaths due to the tumors analyzed. The effect estimates of indoor Rn (3371 sampling points) were adjusted for several parameters, such 
as sociodemographic variables, altitude, and arsenic topsoil levels. The results showed a statistical association between twofold increase in indoor Rn and several cancers in women, included stomach cancer (RR: 1.174; 95\% CI: 1.022-1325) [49]. In contrast, an epidemiologic study conducted in Finland to evaluate the risk of developing stomach cancer due to the presence of $\mathrm{Rn}$ in drinking water showed no association (HR = 0.68, 95\% CI: $0.29-1.59$ at $100 \mathrm{~Bq} / \mathrm{L}$ water), even for Rn concentrations exceeding $300 \mathrm{~Bq} / \mathrm{L}$. This study was conducted for the very high concentrations of several naturally occurring radionuclides in the Finland ground. Only subjects using drilled wells as a source of drinking water were included in the study, and 1492 were the stomach cancers diagnosed during 1981-1995 from the Finnish Cancer Registry [89].

\subsection{Kidney Cancer}

Few scientific works studied Rn exposure and kidney cancer and they are mainly focused on workers (see Table 5).

Table 5. Kidney cancer: Workers.

\begin{tabular}{|c|c|c|c|c|}
\hline $\begin{array}{c}\text { Study } \\
\text { Design }\end{array}$ & $\begin{array}{c}\text { Sample Size } \\
(n)\end{array}$ & $\begin{array}{l}\text { Radon } \\
\text { Conc. }\end{array}$ & Results & $\begin{array}{l}\text { Reference } \\
\text { (Year) }\end{array}$ \\
\hline Cohort study & 5086 & 36.6 WLM & $\begin{array}{l}\text { A significant excess of kidney cancer } \\
\text { deaths was observed }(n=20 ; \\
\mathrm{SMR}=2.0 ; 95 \% \text { CI: } 1.22-3.09), \text { which } \\
\text { was not associated with cumulative } \\
\text { Rn exposure }\end{array}$ & $\begin{array}{l}\text { Vacquier et al. } \\
\text { (2008) [42] }\end{array}$ \\
\hline Cohort study & 28,546 & 21 WLM & $\begin{array}{l}\text { No association for kidney cancer with } \\
\text { increasing cumulative Rn exposure }\end{array}$ & $\begin{array}{l}\text { Navaranjan et al. } \\
\text { (2016) [86] }\end{array}$ \\
\hline Cohort study & $\begin{array}{l}\text { French cohort: } \\
\text { 3377; German } \\
\text { cohort: } 58,986\end{array}$ & $\begin{array}{c}\text { median: } \\
\text { 4.7 WLM range: } \\
\text { 0-128.4 WLM } \\
\text { median: } 18.4 \text { WLM } \\
\text { range: } \\
\text { 0-3224.5 WLM }\end{array}$ & $\begin{array}{c}\text { French cohort } \\
\text { SMR: } 1.49 ; 95 \% \text { CI: } 0.73-2.67 \\
\text { German cohort } \\
\text { SMR = } 0.91 ; 95 \% \text { CI: } 0.77-1.06 \\
\text { No significant association }\end{array}$ & $\begin{array}{c}\text { Drubay et al. } \\
(2014) \text { [90] }\end{array}$ \\
\hline
\end{tabular}

WML: average cumulative exposures; 95\% CI: 95\% confidence interval; SMR: Standardized Mortality Ratio.

Workers and General Population

In an extended follow-up study (1946-1990) performed on 4140 French miners exposed to $\mathrm{Rn}$ for at least 1 year with an average cumulative exposure of $36.6 \mathrm{WLM}$, a significant excess of kidney cancer deaths was observed (SMR: 2.0; 95\% CI: 1.22-3.09). However, no association with cumulative Rn exposure was found [42]. Similarly, Navaranjan et al., evaluating an Ontario uranium miner cohort consisting of 28,546 male miners with a mean cumulative Rn exposure of 21.0 WLM, observed an association with Rn exposure only for lung cancer [86]. Similar results were obtained in French $(n=3377)$ and German $(n=58,986)$ cohorts of uranium miners where deaths from kidney cancer were analyzed. In detail, no significant excess of kidney cancer mortality had been observed neither in the French cohort (SMR: 1.49, 95\% CI: 0.73-2.67) nor in the German cohort (SMR: 0.91; 95\% CI: 0.77-1.06]). Moreover, no significant association between kidney cancer mortality and any type of occupational Rn exposure or kidney equivalent dose had been observed [90]. Finally, in a careful and precise meta-analysis, Chen et al. analyzed several studies carried out in order to verify the relationship between kidney cancer and Rn exposure. Authors concluded how it was not possible to affirm a clear correlation mainly for the lack of homogeneity in the exposure assessment, for the different sample sizes (from 779 to 28,546) and because in many cases kidney cancer mortality rather than incidence was evaluated, thus underestimating the carcinogenic effects of Rn on the kidney. In addition, most of the studies were carried out on mine workers with the possibility of co-exposure to other carcinogenic mineral products such as arsenic, silica dust, and gamma radiation [91]. 


\subsection{Breast Cancer}

Results, mainly focus on general population, are reported in Table 6.

Table 6. Breast cancer: Workers and general population.

\begin{tabular}{|c|c|c|c|c|}
\hline $\begin{array}{l}\text { Study } \\
\text { Design }\end{array}$ & $\begin{array}{l}\text { Sample Size } \\
(n)\end{array}$ & $\begin{array}{l}\text { Radon } \\
\text { Conc. }\end{array}$ & Results & $\begin{array}{l}\text { Reference } \\
\text { (Year) }\end{array}$ \\
\hline Cohort study & $\begin{array}{l}\text { School employees: } \\
520\end{array}$ & $\begin{array}{c}\text { Classrooms: } \\
<2 \text { pCi/L Utility tunnels: } \\
\text { 29-33 pCi/L }\end{array}$ & SMR: 5; 95\% CI: 1.03-14.6 & $\begin{array}{l}\text { Neuberger et al. } \\
\text { (1997) [92] }\end{array}$ \\
\hline $\begin{array}{l}\text { Observational } \\
\text { cohort study }\end{array}$ & 74,806 & ${ }^{1}$ water: $1.3-9 \mathrm{~Bq} / \mathrm{L}$ & HR: $1.59 ; 95 \% C I: 1.10-2.31$ & $\begin{array}{l}\text { Kristbjornsdottir et al. } \\
\text { (2012) [93] }\end{array}$ \\
\hline $\begin{array}{l}\text { Prospective cohort } \\
\text { study }\end{array}$ & 811,961 & $\begin{array}{c}\text { mean } \pm \text { sd: } 53.5 \pm 38.0 \\
\mathrm{~Bq} / \mathrm{m}^{3} \text { range: } \\
6.3-265.7 \mathrm{~Bq} / \mathrm{m}^{3}\end{array}$ & HR: 0.91; 95\% CI: 0.82-1.01 & $\begin{array}{l}\text { Turner et al. } \\
\text { (2012) [46] }\end{array}$ \\
\hline $\begin{array}{l}\text { Prospective cohort } \\
\text { study }\end{array}$ & 112,639 female & $\begin{array}{c}2 \text { P20: }<27.0 \mathrm{~Bq} / \mathrm{m}^{32} \\
\text { P40: } \geq 27.0-37.7 \mathrm{~Bq} / \mathrm{m}^{3} \\
2 \text { P60: } \geq 37.7-50.1 \mathrm{~Bq} / \mathrm{m}^{3} \\
2 \text { P80: } \geq 50.1-74.9 \mathrm{~Bq} / \mathrm{m}^{3} \\
2 \text { P100: } \geq 74.9 \mathrm{~Bq} / \mathrm{m}^{3}\end{array}$ & $\begin{array}{c}\text { For women in the highest } \\
\text { quintile of exposure } \\
\left(\geq 74.9 \mathrm{~Bq} / \mathrm{m}^{3}\right) \\
\mathrm{HR}=1.38 ; 95 \% \mathrm{CI}: 0.97-1.96 \\
\text { (ER-/PR-) } \\
\text { No association was observed } \\
\text { for ER+/PR+ breast cancer }\end{array}$ & $\begin{array}{l}\text { VoPham et al. } \\
\text { (2017) [94] }\end{array}$ \\
\hline
\end{tabular}

${ }^{1}$ Geothermal hot water from drilled wells; ${ }^{2}$ P20: 1st quintile, P40: 2nd quintile, P60: 3rd quintile, P80: 4th quintile, and P100: 5th quintile; 95\% CI: 95\% confidence interval; SMR: Standardized Mortality Ratio; HR: Hazard Ratio; ER-/PR-: Estrogen Receptor negative/Progesterone receptor negative; ER+/PR+: Estrogen Receptor negative/Progesterone receptor negative.

\section{Workers and General Population}

Increased breast cancer incidence was observed among former female employees of a Missouri school with elevated Rn levels [93]. In contrast, ecologic studies in the U.S. showed no association between county-level Rn concentrations and breast cancer incidence [95]. Later, a perspective analysis carried out in the American Cancer Society cohort showed no association between Rn exposure and breast cancer-related mortality [46]. Recently, also in the USA, VoPham et al. examined the association between environmental Rn levels and breast cancer incidence in a prospective cohort of non-occupationally exposed of 112,639 females. Increasing Rn exposure was not associated with breast cancer risk overall. However, women in the highest quintile of exposure $\left(\geq 74.9 \mathrm{~Bq} / \mathrm{m}^{3}\right)$ showed an elevated risk of ER-/PR- breast cancer compared to women in the lowest quintile $\left(<27.0 \mathrm{~Bq} / \mathrm{m}^{3}\right)$. No association was observed for ER+/PR+ breast cancer [95]. Finally, breast cancer incidence in Iceland resulted higher among residents of high temperature geothermal areas and higher level of $\mathrm{Rn}$ in water compared to residents of non-geothermal areas [93].

\section{Discussion}

The possible etiologic relationship between $\mathrm{Rn}$ and tumor sites other than lung, as well as the pathogenic mechanism, are controversial. In this review, we analyzed the epidemiologic evidence in the development of tumors other than lung cancer in both occupational and environmental Rn exposure. Several large-scale studies were launched in an effort to investigate factors possibly affecting dose-response relationship and $\mathrm{Rn}$ exposure in other than lung cancer. As far as occupational exposure is concerned, literature data refer almost exclusively to miners, while for environmental exposure, the research work focuses on both inhalation and ingestion exposure due to the presence of Rn in water. For their greater risk of developing cancer diseases because of radiation exposure compared to adults, the outcomes of studies related to children were also analyzed.

Even if the mechanism whereby $\mathrm{Rn}$ initiates tumorigenesis is not completely known, literature data indicate that there are several tumor pathologies that can develop following 
occupational and environmental exposure. Lung cancer is certainly the most frequent disease for which the results of the literature largely confirm the etiological role of $\mathrm{Rn}$ and its products. However, their effect in reference to other organs is still rather elusive and sometimes contradictory. The risk depends on the concentration of Rn and its products as well as on the time spent in their presence [96], even if there is general agreement in the assumption that there is no exposure threshold value below which one can be considered protected. The probability of oncogenic phenomena, in fact, does not depend on the number of radiations that affect a single cell, but on the total number of interactions between cells and radiations, which is proportional to the exposure (International Commission on Radiation Units and Measurements, 1980.) [36].

Among other than lung cancers, we first considered brain and CNS cancer because they have been associated with ionizing radiation exposure [97,98]. The cumulative dose in brain could be a consequence to the transport of $\mathrm{Rn}$ and its progeny through the blood together with the fact that particles with aerodynamic diameter around $1 \mathrm{~nm}$ and a high extrathoracic deposition including the nasal cavity could reach the brain via the olfactory neuronal pathway [47]. Additionally, it has been proposed that macrophages might phagocyte small solid particles in the lungs that could reach the brain through the blood [99]. The weight of evidence from high-dose occupational studies suggests $\mathrm{Rn}^{\prime} \mathrm{s}$ potential role in brain and CNS cancer development. Nevertheless, very few studies have assessed the relationship between Rn levels and brain or CNS tumors. Most studies of mineworkers showed no relationship between occupational exposure and incidence or mortality for these cancers, while assessment of general population provided mixed results. Some papers have evaluated the impact of Rn not only in adults but also in children. In fact, CNS tumors are the second most common cancer worldwide in children aged 0-14 years, after leukemia. In addition, the United Nations Scientific Committee on the Effects of Atomic Radiation has suggested a greater risk for children compared to adults of radiation-induction of some cancer types, including CNS tumors [100]. Despite this, even in the case of children, results are inconclusive.

Similarly, risks of developing leukemia following protracted exposure to very low levels of radiation, such as those due to background radiation, are still in dispute. It has been clearly established that acute or repeated exposure to high dose ionizing radiation induces leukemia. Less is known about the effects of Rn decay alpha particles on the bone marrow. However, a recent study reported that the bronchial mucosa has an abundance of circulating lymphocytes, thus suggesting that Rn decay particles exposures could be associated with hematologic cancers originating from these cells [101]. Several studies evaluated leukemia related to occupational and environmental Rn exposure, suggesting a correlation between indoor levels and leukemia incidence at all ages $[65,70,73,74,102]$. With regard to childhood leukemia, the most common cancer diagnosed in children worldwide, Rn level in dwellings showed an increase in risk in numerous studies [70,71], but bias and confounding factors cannot be ruled out as possible explanations.

Environmental $\mathrm{Rn}$ is also relevant for skin exposure because it attaches to aerosol particles in the air, which adhere to the human skin via electrostatic attraction. Subsequently, the alpha particles from Rn decay irradiate the skin's outer layer. Therefore, the skin receives the second-highest dose after the respiratory tract; an annual dose for the skin at $200 \mathrm{~Bq} / \mathrm{m}^{3}$ is estimated to be $25 \mathrm{mSv}$ [103]. The critical cells in the skin are located in the basal layer of the epidermis, and the emitted alpha particles must penetrate the outer layers to reach these cells. Eatough et al. estimated that, for nuclides attached to the actual skin surface, the dose to the basal layer is around $0.5 \mu \mathrm{Sv}$ decay- $1 \mathrm{~cm}^{2}$ for ${ }^{218} \mathrm{Po}$, which emits a $6.0 \mathrm{MeV}$ alpha particle, and $1 \mu \mathrm{Sv}$ decay- $1 \mathrm{~cm}^{2}$ for ${ }^{214} \mathrm{Po}$, with a $7.69 \mathrm{MeV}$ alpha [104]. Despite this, only scarce research on the association between skin cancer and Rn has been conducted with mixed results due to low numbers and heterogeneity of studies.

Stomach cancer has been considered because groundwater is a source of indoor air contamination due to $\mathrm{Rn}^{\prime}$ transfer from water to air during showers, laundry, and washing dishes. Rn dissolved in water might be riskier for stomach cells because the stomach 
is a storage organ and exposure might be prolonged [105]. Various models have been developed for estimating the radiation dose to different organs and tissues from ingested $\mathrm{Rn}$, but there is no consensus about the doses. The NRC has proposed a conversion factor of $3.5 \times 10^{-9} \mathrm{~Sv} / \mathrm{Bq}$ for calculating the dose to the stomach due to Rn in drinking water [106]. The results of studies conducted to verify an association between exposure to $\mathrm{Rn}$ and stomach cancer are mixed, although with some prevalence for results with a positive association.

The hypothesis that $\mathrm{Rn}$ can cause kidney cancer is biologically plausible because the kidney filters Rn and its decay products from the blood. During this process, the radioactive alpha particles interact with renal cells directly and exert carcinogenic effects on the kidney [70]. Again, few studies have been reported about kidney cancers and Rn exposure, and these only referred to workers. Generally, no association has been found, even if a possible association cannot be definitively excluded.

Though the molecular mechanisms underlying the effects of $\mathrm{Rn}$ on breast cancer risk are not fully understood, Rn and its decay products have been suspected to deliver radiation doses to breast tissue [95]. In fact, based on its lipophilic properties, biokinetic models estimated the deliverable concentrations of $\mathrm{Rn}$ decay products detected in the breast at an annual dose of $1000 \mathrm{~Bq} / \mathrm{L}$ (or $2.7 \times 104 \mathrm{pCi} / \mathrm{L}$ ) [99]. However, even in the case of breast cancer, few studies have been carried out about the association between $\mathrm{Rn}$ exposure and the development of neoplasia, and generally, increasing exposure was not associated with breast cancer risk overall.

Because of considerable experience gained by studying health effects in miners who worked in Rn-rich environments, the radioactive $\mathrm{Rn}$ and its progeny were identified as a cause of lung-cancer [36]. The lung is the main target organ, but it should not be considered the exclusive one. Rn enters the body principally through the respiratory system where further decay occurs, causing oxidative damage to DNA, proteins, and lipids (UNSCEAR, 2000). Rn and its progeny can settle in lungs, where they continue to undergo radioactive decay and give a radiation dose to tissues, potentially capable of irreversibly damaging the cells. Moreover, from the respiratory tree, they can pass the capillaryalveolus barrier and spread systemically to other organs. Alpha particles represent the predominant form of radiation emitted as a result of the decay of Rn (Figure 1). The most substantial alpha emitters from Rn decay are ${ }^{218} \mathrm{Po}(6.0 \mathrm{MeV})$ and ${ }^{214} \mathrm{Po}(7.69 \mathrm{MeV})$, and they have penetration depths of $47 \mu \mathrm{m}$ and $70 \mu \mathrm{m}$, respectively [99], suggesting high levels of irradiation, particularly of the bronchial epithelium and at bifurcation sites, when inhaled into the lungs [3,107]. Inhaled decay products, largely attached to particulate matter always present in the air, settle on the walls of the respiratory system and from here irradiate, through alpha radiation, bronchial cells. Despite their limited tissue penetration capability, alpha particles can cause significant biological damage in exposed tissue due to their high relative biological effectiveness. In fact, they generate free radicals and oxidative stress, which can directly damage DNA in exposed cell nuclei. A variety of genetic lesions, including chromosomal damage, gene mutations, induction of micronuclei, and sister chromatid exchange (SCE), have been associated with the DNA damaging effects of alpha particles [108-114]. Rn exposure also correlates with tumor mutation burden (TMB), and subjects with a high exposure have almost twice as many mutations/Mb compared with those with low exposures. Apparently, this mutational signature is associated with defective DNA mismatch repair [115]. There is also evidence that adjacent cells may sustain damage via a "bystander effect", phenomenon for which no irradiated cells respond to signals emitted by adjacent irradiated cells [116]. Brenner et al. suggests that the bystander effects can result in non-linear dose-response relations and inverse dose-rate effects [117]. Several identified outcomes have been attributed to the bystander effect including chromosome aberration (CAs), micronuclei formation (MN) and sister chromatid exchange (SCEs), apoptotic progression and inhibition, modification of gene and protein expression, neoplastic transformation, mutagenesis, cytokine and growth factor production, and generation of $\gamma-\mathrm{H} 2 \mathrm{AX}$ species, indicative of double strand DNA breaks [112,118-120]. 
However, recently, much interest has been generated by the theory of hormesis according to which low levels of radiation exposure could have a protective effect. In the case of $\mathrm{Rn}$, this theory refers to a protective effect of low-level Rn exposure against lung cancer in smokers. A possible explanation is that this low-dose exposure may eliminate the smoke-injured cells by stimulation of apoptosis and immunity [121-124].

\section{Conclusions}

Epidemiological data on Rn exposure and cancer risk confirm the lack of a clear prevalence of other than lung cancer. This is mainly due to the limited number of studies but also to the fact that they are heterogeneous with bias or several confounding factor, which makes the results less reliable. The study of Rn exposure and its health effects includes many aspects ranging from risk assessment to techniques for reduction, passing through the identification of areas with high concentrations, knowledge of the factors affecting concentrations, measurement techniques, remedial actions, and the definition of regulations. Each of these aspects requires considerable efforts and skills, and the investigation methods must always deal with the complexity of the phenomenon due to the multiplicity of sources that produce it.

The health risks associated with exposure to Rn appear to be high and require the definition of investigation plans at an international level, for further development of policies to prevent and reduce the risk. A careful evaluation and an in-depth study of the pathogenetic mechanisms that exist between exposure to Rn and the onset of pathological processes are required, in order to implement more effective primary prevention.

Author Contributions: Conceptualization, P.M. and D.P.; methodology, P.M. and D.P.; validation, P.M., D.P., S.P., M.C. and S.R.; formal analysis, P.M. and D.P.; investigation, P.M., D.P., S.R. and S.P.; data curation, S.P., D.C. and M.C.; writing-original draft preparation, P.M. and D.P.; writing—review and editing, M.C., S.R. and D.C.; supervision, P.M. and D.P. All authors have read and agreed to the published version of the manuscript.

Funding: This research received no external funding.

Institutional Review Board Statement: Not applicable.

Informed Consent Statement: Not applicable.

Data Availability Statement: Not applicable.

Conflicts of Interest: The authors declare no conflict of interest.

\section{Appendix A}

Radon Measurement Units

Bequerel $(\mathrm{Bq})=$ one radioactive disintegration per second. It is a measure of radioactivity; $\mathrm{Bq} / \mathrm{m}^{3}=$ number of decays of $\mathrm{Rn}$ per second in one cubic meter of air;

Curie $(\mathrm{Ci})=$ the activity of one gram of $\mathrm{Rn}$ in radioactive equilibrium;

$\mathrm{pCi}=10^{-12}$ Curie;

$\mathrm{pCi} / 1=37 \mathrm{~Bq} / \mathrm{m}^{3}$;

Sievert $(\mathrm{Sv})=$ absorbed dose of any ionizing radiation having the same biological efficacy as 1 gray of $X$-rays;

$\mathrm{mSv}=10^{-3} \mathrm{~Sv}$;

Working Level $(\mathrm{WL})=$ any combination of short-lived radon daughters in $1 \mathrm{~L}$ of air with the potential of emitting $1.3 \times 10^{5} \mathrm{MeV}$ of alpha particle energy during decay;

Working Level Month (WLM) $=1 \mathrm{WL}$ exposure for $170 \mathrm{~h}$. 


\section{References}

1. Polpong, P.; Bovornkitti, S. Indoor radon. J. Med. Assoc. Thai. 1998, 81, 47-57.

2. Friedmann, H.; Baumgartner, A.; Bernreiter, M.; Gräser, J.; Gruber, V.; Kabrt, F.; Kaineder, H.; Maringer, F.J.; Ringer, W.; Seidel, C.; et al. Indoor radon, geogenic radon surrogates and geology-Investigations on their correlation. J. Environ. Radioact. 2017, 166, 382-389. [CrossRef]

3. Robertson, A.; Allen, J.; Laney, R.; Curnow, A. The cellular and molecular carcinogenic effects of radon exposure: A review. Int. J. Mol. Sci. 2013, 5, 14024-14063. [CrossRef]

4. Akiba, S.; Tokonami, S.; Bochicchio, F.; McLaughlin, J.; Tommasino, L.; Harley, N. Thoron: Its metrology, health effects and implications for radon epidemiology: A summary of roundtable discussions. Radiat. Prot. Dosim. 2010, 141, 477-481. [CrossRef]

5. Steinhausler, F.; Hofmann, W.; Lettner, H. Thoron exposure of man: A negligible issue? Radiat. Prot. Dosim. 1994, 56, 1-4. [CrossRef]

6. Amrane, M.; Oufni, L.; Misdaq, M.A. Attached and unattached fractions of short-lived radon decay products in outdoor environments: Effect on the human respiratory system. Radiat. Prot. Dosim. 2014, 162, 400-409. [CrossRef] [PubMed]

7. Porstendörfer, J.; Pagelkopf, P.; Gründel, M. Fraction of the positive 218Po and 214Pb clusters in indoor air. Radiat. Prot. Dosim. 2005, 113, 342-351. [CrossRef] [PubMed]

8. Appleton, J.D. Radon: Sources, health risks, and hazard mapping. Ambio 2007, 36, 85-89. [CrossRef]

9. Daniels, R.D.; Schubauer-Berigan, M.K. Radon in us workplaces: A review. Radiat. Prot. Dosim. 2017, 176, 278-286. [CrossRef]

10. Craft, B.F.; Oser, J.L.; Norris, F.W. A method for determining relative amounts of combined and uncombined radon daughter activity in underground uranium mines. Am. Ind. Hyg. Assoc. J. 1966, 27, 154-159. [CrossRef]

11. Jedrychowski, W.; Flak, E.; Wesolowski, J.; Liu, K.S. Relation between residential radon concentrations and housing characteristics. The Cracow Study. Cent. Eur. J. Public Health 1995, 3, 158-160.

12. Stanley, F.K.; Zarezadeh, S.; Dumais, C.D.; Dumais, K.; MacQueen, R.; Clement, F.; Goodarzi, A.A. Comprehensive survey of household radon gas levels and risk factors in southern Alberta. CMAJ Open 2017, 28, E255-E264. [CrossRef]

13. Lee, C.; Lee, D. Review of domestic and international methods of measuring radon in residential buildings. Ann. Occup. Environ. Med. 2016, 28, 14. [CrossRef]

14. Noh, J.; Sohn, J.; Cho, J.; Kang, D.R.; Joo, S.; Kim, C.; Shin, D.C. Residential radon and environmental burden of disease among Non-smokers. Ann. Occup. Environ. Med. 2016, 28, 12. [CrossRef]

15. Bard, D.; Tirmarche, M.; Pirard, P. Exposition au radon et risques pour la santé publique [Radon exposure and risks for public health]. Ann. Pharm. Fr. 2000, 58, 373-382. (In French)

16. Nazaroff, W.M. Entry by pressure-driven flow or molecular diffusion? A reassessment of $222 \mathrm{Rn}$ concentrations measured in an energy-efficient house. Health Phys. 1988, 55, 1005-1011. [CrossRef]

17. Villalba, L.; Colmenero Sujo, L.; Montero Cabrera, M.E.; Cano Jiménez, A.; Rentería Villalobos, M.; Delgado Mendoza, C.J.; Jurado Tenorio, L.A.; Dávila Rangel, I.; Herrera Peraza, E.F. Radon concentrations in ground and drinking water in the state of Chihuahua, Mexico. J. Environ. Radioact. 2005, 80, 139-151. [CrossRef]

18. Chen, J. A discussion on issues with radon in drinking water. Radiat. Prot. Dosim. 2019, 185, 526-531. [CrossRef]

19. Cho, B.W.; Kim, H.K.; Kim, M.S.; Hwang, J.H.; Yoon, U.; Cho, S.Y.; Choo, C.O. Radon concentrations in the community groundwater system of South Korea. Environ. Monit. Assess. 2019, 191, 189. [CrossRef]

20. Official Journal on European Community, $\mathrm{N}^{\circ}$ L 80/26, 27.3.90. Available online: https://eur-lex.europa.eu/legal-content/EN/ TXT/PDF/?uri=CELEX:31990H0143\&from=IT (accessed on 28 September 2021).

21. Official Journal on European Community, $N^{\circ}$ L 159/1, 29.6.96. Available online: https:/ / eur-lex.europa.eu/legal-content/EN/ TXT/PDF/?uri=CELEX:31996L0029\&from=EN (accessed on 28 September 2021).

22. Official Journal on European Community, $\mathrm{N}^{\circ} 13 / 1,17.1 .2014$. Available online: https:/ / eur-lex.europa.eu/legal-content/EN/ TXT/PDF/?uri=CELEX:32013L0059\&qid=1630058541624\&from=EN (accessed on 28 September 2021).

23. Gordon, K.; Terry, P.D.; Liu, X.; Harris, T.; Vowell, D.; Yard, B.; Chen, J. Radon in Schools: A Brief Review of State Laws and Regulations in the United States. Int. J. Environ. Res. Public Health 2018, 15, 2149. [CrossRef]

24. Western Australian Legislation, Radiation Safety Act 1975. Available online: https://www.legislation.wa.gov.au/legislation/ statutes.nsf/main_mrtitle_784_homepage.html (accessed on 28 September 2021).

25. Western Australian Legislation, Mines Safety and Inspection Act 1994. Available online: https://www.legislation.wa.gov.au/ legislation/statutes.nsf/main_mrtitle_599_homepage.html (accessed on 28 September 2021).

26. Western Australian Legislation, Mines Safety and Inspection Regulations 1995. Available online: https://www.legislation.wa. gov.au/legislation/statutes.nsf/main_mrtitle_1819_homepage.html (accessed on 28 September 2021).

27. Bolck, F. Man-Made Mineral Fibres and Radon IARC Monographs on the Evaluation of the Carcinogenic Risks to Humans; IARC: Lyon, France, 1990; Volume 43.

28. WHO. Indoor Radon a Public Health Perspective. A Public Health Perspective; WHO: Geneva, Switzerland, 2009.

29. Puskin, J.S.; James, A.C. Radon exposure assessment and dosimetry applied to epidemiology and risk estimation. Radiat. Res. 2006, 166, 193-208. [CrossRef] [PubMed]

30. Krewski, D.; Lubin, J.H.; Zielinski, J.M.; Alavanja, M.; Catalan, V.S.; Field, R.W.; Klotz, J.B.; Létourneau, E.G.; Lynch, C.F.; Lyon, J.L.; et al. A combined analysis of North American case-control studies of residential radon and lung cancer. J. Toxicol. Environ. Health Part A 2006, 69, 533-597. [CrossRef] [PubMed] 
31. National Library of Medicine. Available online: https:/ / pubmed.ncbi.nlm.nih.gov / (accessed on 28 September 2021).

32. Elsevier. Available online: https:/ / scopus.com (accessed on 28 September 2021).

33. Web of Science. Available online: https:/ / webofscience.com (accessed on 28 September 2021).

34. U.S. Environmental Protection Agency-Radon. Available online: https:/ / www.epa.gov/radon (accessed on 28 September 2021).

35. Cool, D.A.; Kase, K.R.; Boice, J.D. NCRP Report no.180-management of exposure to ionizing radiation: NCRP radiation protection guidance for the United States. J. Radiol. Prot. 2019, 39, 966-977. [CrossRef] [PubMed]

36. Beir, V.I.; National Research Council. Committee on Health Risks of Exposure to Radon (BEIR VI). Health Effects of Exposure to Radon: BEIR VI; National Academies Press: Washington, DC, USA, 1999.

37. IARC-WHO. Available online: https:/ / www.iarc.who.int/ (accessed on 28 September 2021).

38. Center for Disease Control and Prevention - The National Institute for Occupational Safety and Health (NIOSH). Available online: https: / / www.cdc.gov/niosh/ (accessed on 28 September 2021).

39. Tirmarche, M.; Raphalen, A.; Allin, F.; Chameaud, J.; Bredon, P. Mortality of a cohort of French uranium miners exposed to relatively low radon concentrations. Br. J. Cancer 1993, 67, 1090-1097. [CrossRef]

40. Darby, S.C.; Whitley, E.; Howe, G.R.; Hutchings, S.J.; Kusiak, R.A.; Lubin, J.H.; Morrison, H.I.; Tirmarche, M.; Tomásek, L.; Radford, E.P.; et al. Radon and cancers other than lung cancer in underground miners: A collaborative analysis of 11 studies. J. Natl. Cancer Inst. 1995, 87, 378-384. [CrossRef]

41. Darby, S.C.; Radford, E.P.; Whitley, E. Radon exposure and cancers other than lung cancer in Swedish iron miners. Environ. Health Perspect. 1995, 103 (Suppl. 2), 45-47. [CrossRef]

42. Vacquier, B.; Caer, S.; Rogel, A.; Feurprier, M.; Tirmarche, M.; Luccioni, C.; Quesne, B.; Acker, A.; Laurier, D. Mortality risk in the French cohort of uranium miners: Extended follow-up 1946-1999. Occup. Environ. Med. 2008, 65, 597-604. [CrossRef]

43. Kreuzer, M.; Walsh, L.; Schnelzer, M.; Tschense, A.; Grosche, B. Radon and risk of extrapulmonary cancers: Results of the German uranium miners' cohort study, 1960-2003. Br. J. Cancer 2008, 99, 1946-1953. [CrossRef]

44. Schubauer-Berigan, M.K.; Daniels, R.D.; Pinkerton, L.E. Radon exposure and mortality among white and American Indian uranium miners: An update of the Colorado Plateau cohort. Am. J. Epidemiol. 2009, 169, 718-730. [CrossRef]

45. Vacquier, B.; Rage, E.; Leuraud, K.; Caër-Lorho, S.; Houot, J.; Acker, A.; Laurier, D. The influence of multiple types of occupational exposure to radon, gamma rays and long-lived radionuclides on mortality risk in the French "post-55" sub-cohort of uranium miners: 1956-1999. Radiat. Res. 2011, 176, 796-806. [CrossRef]

46. Turner, M.C.; Krewski, D.; Chen, Y.; Pope, C.A., 3rd; Gapstur, S.M.; Thun, M.J. Radon and nonrespiratory mortality in the American Cancer Society cohort. Am. J. Epidemiol. 2012, 176, 808-814. [CrossRef]

47. Bräuner, E.V.; Andersen, Z.J.; Andersen, C.E.; Pedersen, C.; Gravesen, P.; Ulbak, K.; Hertel, O.; Loft, S.; Raaschou-Nielsen, O. Residential radon and brain tumour incidence in a Danish cohort. PLoS ONE. 2013, 8, e74435. [CrossRef]

48. Ruano-Ravina, A.; Aragonés, N.; Kelsey, K.T.; Pérez-Ríos, M.; Piñeiro-Lamas, M.; López-Abente, G.; Barros-Dios, J.M. Residential radon exposure and brain cancer: An ecological study in a radon prone area (Galicia, Spain). Sci. Rep. 2017, 7, 3595. [CrossRef]

49. López-Abente, G.; Núñez, O.; Fernández-Navarro, P.; Barros-Dios, J.M.; Martín-Méndez, I.; Bel-Lan, A.; Locutura, J.; Quindós, L.; Sainz, C.; Ruano-Ravina, A. Residential radon and cancer mortality in Galicia, Spain. Sci. Total Environ. 2018, 610, 1125-1132. [CrossRef]

50. Monastero, R.N.; Meliker, J.R. Incidence of brain and spinal cord cancer and county-level radon levels in New Jersey, Wisconsin, Minnesota, Pennsylvania, and Iowa, USA. Environ. Geochem. Health 2020, 42, 389-395. [CrossRef]

51. Collman, G.W.; Loomis, D.P.; Sandler, D.P. Childhood cancer mortality and radon concentration in drinking water in North Carolina. Br. J. Cancer 1991, 63, 626-629. [CrossRef]

52. Kaletsch, U.; Kaatsch, P.; Meinert, R.; Schüz, J.; Czarwinski, R.; Michaelis, J. Childhood cancer and residential radon exposureresults of a population-based case-control study in Lower Saxony (Germany). Radiat. Environ. Biophys. 1999, 38, 211-215. [CrossRef]

53. Raaschou-Nielsen, O.; Andersen, C.E.; Andersen, H.P.; Gravesen, P.; Lind, M.; Schüz, J.; Ulbak, K. Domestic radon and childhood cancer in Denmark. Epidemiology 2008, 19, 536-543. [CrossRef]

54. Hauri, D.; Spycher, B.; Huss, A.; Zimmermann, F.; Grotzer, M.; von der Weid, N.; Weber, D.; Spoerri, A.; Kuehni, C.E.; Röösli, M.; et al. Domestic radon exposure and risk of childhood cancer: A prospective census-based cohort study. Environ. Health Perspect. 2013, 121, 1239-1244. [CrossRef]

55. Kendall, G.M.; Little, M.P.; Wakeford, R.; Bunch, K.J.; Miles, J.C.; Vincent, T.J.; Meara, J.R.; Murphy, M.F. A record-based case-control study of natural background radiation and the incidence of childhood leukaemia and other cancers in Great Britain during 1980-2006. Leukemia 2013, 27, 3-9. [CrossRef]

56. Del Risco Kollerud, R.; Blaasaas, K.G.; Claussen, B. Risk of leukaemia or cancer in the central nervous system among children living in an area with high indoor radon concentrations: Results from a cohort study in Norway. Br. J. Cancer 2014, 111, 1413-1420. [CrossRef] [PubMed]

57. Berlivet, J.; Hémon, D.; Cléro, É.; Ielsch, G.; Laurier, D.; Guissou, S.; Lacour, B.; Clavel, J.; Goujon, S. Ecological association between residential natural background radiation exposure and the incidence rate of childhood central nervous system tumors in France, 2000-2012. J. Environ. Radioact. 2020, 211, 106071. [CrossRef] [PubMed]

58. Walsh, L.; Dufey, F.; Tschense, A.; Schnelzer, M.; Grosche, B.; Kreuzer, M. Radon and the risk of cancer mortality-Internal Poisson models for the German uranium miners cohort. Health Phys. 2010, 99, 292-300. [CrossRef] [PubMed] 
59. Hess, C.T.; Weiffenbach, C.V.; Norton, S.A. Environmental radon and cancer correlations in Maine. Health Phys. 1983, 45, 339-348. [CrossRef]

60. Ruano-Ravina, A.; Dacosta-Urbieta, A.; Barros-Dios, J.M.; Kelsey, K.T. Radon exposure and tumors of the central nervous system. Gac. Sanit. 2018, 32, 567-575. [CrossRef]

61. Tomásek, L.; Darby, S.C.; Swerdlow, A.J.; Placek, V.; Kunz, E. Radon exposure and cancers other than lung cancer among uranium miners in West Bohemia. Lancet 1993, 341, 919-923. [CrossRef]

62. Rericha, V.; Kulich, M.; Rericha, R.; Shore, D.L.; Sandler, D.P. Incidence of leukemia, lymphoma, and multiple myeloma in Czech uranium miners: A case-cohort study. Environ. Health Perspect. 2006, 114, 818-822. [CrossRef]

63. Zablotska, L.B.; Lane, R.S.; Frost, S.E.; Thompson, P.A. Leukemia, lymphoma and multiple myeloma mortality (1950-1999) and incidence (1969-1999) in the Eldorado uranium workers cohort. Environ. Res. 2014, 130, 43-50. [CrossRef]

64. Kelly-Reif, K.; Sandler, D.P.; Shore, D.; Schubauer-Berigan, M.; Troester, M.A.; Nylander-French, L.; Richardson, D.B. Mortality and cancer incidence among underground uranium miners in the Czech Republic 1977-1992. Occup. Environ. Med. 2019, 76, 511-518. [CrossRef]

65. Eatough, J.P.; Henshaw, D.L. Radon and monocytic leukaemia in England. J. Epidemiol. Community Health 1993, 47, 506-507. [CrossRef]

66. Thorne, R.; Foreman, N.K.; Mott, M.G. Radon in Devon and Cornwall and paediatric malignancies. Eur. J. Cancer. 1996, 32, 282-285. [CrossRef]

67. Steinbuch, M.; Weinberg, C.R.; Buckley, J.D.; Robison, L.L.; Sandler, D.P. Indoor residential radon exposure and risk of childhood acute myeloid leukaemia. Br. J. Cancer 1999, 81, 900-906. [CrossRef]

68. Lubin, J.H.; Linet, M.S.; Boice, J.D., Jr.; Buckley, J.; Conrath, S.M.; Hatch, E.E.; Kleinerman, R.A.; Tarone, R.E.; Wacholder, S.; Robison, L.L. Case-control study of childhood acute lymphoblastic leukemia and residential radon exposure. J. Natl. Cancer Inst. 1998, 90, 294-300. [CrossRef]

69. UK Childhood Cancer Study Investigators. The United Kingdom Childhood Cancer Study of exposure to domestic sources of ionising radiation: 1: Radon gas. Br. J. Cancer 2002, 86, 1721-1726. [CrossRef]

70. Henshaw, D.L.; Eatough, J.P.; Richardson, R.B. Radon as a causative factor in induction of myeloid leukaemia and other cancers. Lancet 1990, 335, 1008-1012. [CrossRef]

71. Gilman, E.A.; Knox, E.G. Geographical distribution of birth places of children with cancer in the UK. Br. J. Cancer 1998, 77, 842-849. [CrossRef]

72. Kohli, S.; Noorlind Brage, H.; Löfman, O. Childhood leukaemia in areas with different radon levels: A spatial and temporal analysis using GIS. J. Epidemiol. Community Health 2000, 54, 822-826. [CrossRef]

73. Lucie, N.P. Radon exposure and leukaemia. Lancet 1989, 2, 99-100. [CrossRef]

74. Alexander, F.E. Radon and leukaemia. Lancet 1990, 335, 1336-1340.

75. Muirhead, C.R.; Butland, B.K.; Green, B.M.; Draper, G.J. Childhood leukaemia and natural radiation. Lancet 1991, 337, 503-504. [CrossRef]

76. Tong, J.; Qin, L.; Cao, Y.; Li, J.; Zhang, J.; Nie, J.; An, Y. Environmental radon exposure and childhood leukemia. J. Toxicol. Environ. Health B Crit. Rev. 2012, 15, 332-347. [CrossRef] [PubMed]

77. Schüz, J.; Erdmann, F. Environmental Exposure and Risk of Childhood Leukemia: An Overview. Arch. Med. Res. 2016, 47, 607-614. [CrossRef] [PubMed]

78. Etherington, D.J.; Pheby, D.F.; Bray, F.I. An ecological study of cancer incidence and radon levels in South West England. Eur. J. Cancer 1996, 32, 1189-1197. [CrossRef]

79. Wheeler, B.W.; Allen, J.; Depledge, M.H.; Curnow, A. Radon and skin cancer in southwest England: An ecologic study. Epidemiology 2012, 23, 44-52. [CrossRef]

80. Wheeler, B.W.; Kothencz, G.; Pollard, A.S. Geography of non-melanoma skin cancer and ecological associations with environmental risk factors in England. Br. J. Cancer 2013, 109, 235-241. [CrossRef]

81. Bräuner, E.V.; Loft, S.; Sørensen, M.; Jensen, A.; Andersen, C.E.; Ulbak, K.; Hertel, O.; Pedersen, C.; Tjønneland, A.; Krüger Kjær, S.; et al. Residential Radon Exposure and Skin Cancer Incidence in a Prospective Danish Cohort. PLoS ONE 2015, 10, e0135642. [CrossRef]

82. Barbosa-Lorenzo, R.; Barros-Dios, J.M.; Raíces Aldrey, M.; Cerdeira Caramés, S.; Ruano-Ravina, A. Residential radon and cancers other than lung cancer: A cohort study in Galicia, a Spanish radon-prone area. Eur. J. Epidemiol. 2016, 31, 437-441. [CrossRef]

83. Vienneau, D.; de Hoogh, K.; Hauri, D.; Vicedo-Cabrera, A.M.; Schindler, C.; Huss, A.; Röösli, M.; SNC Study Group. Effects of Radon and UV Exposure on Skin Cancer Mortality in Switzerland. Environ. Health Perspect. 2017, 125, 67009. [CrossRef]

84. Charles, M.W. Radon exposure of the skin: II. Estimation of the attributable risk for skin cancer incidence. J. Radiol. Prot. 2007, 27, 253-274. [CrossRef]

85. Denman, A.R.; Eatough, J.P.; Gillmore, G.; Phillips, P.S. Assessment of health risks to skin and lung of elevated radon levels in abandoned mines. Health Phys. 2003, 85, 733-739. [CrossRef]

86. Navaranjan, G.; Berriault, C.; Do, M.; Villeneuve, P.J.; Demers, P.A. Cancer incidence and mortality from exposure to radon progeny among Ontario uranium miners. Occup. Environ. Med. 2016, 73, 838-845. [CrossRef]

87. Messier, K.P.; Serre, M.L. Lung and stomach cancer associations with groundwater radon in North Carolina, USA. Int. J. Epidemiol. 2017, 46, 676-685. [CrossRef] 
88. Kjellberg, S.; Wiseman, J.S. The relationship of radon to gastrointestinal malignancies. Am. Surg. 1995, 61, 822-825.

89. Auvinen, A.; Salonen, L.; Pekkanen, J.; Pukkala, E.; Ilus, T.; Kurttio, P. Radon and other natural radionuclides in drinking water and risk of stomach cancer: A case-cohort study in Finland. Int. J. Cancer 2005, 114, 109-113. [CrossRef]

90. Drubay, D.; Ancelet, S.; Acker, A.; Kreuzer, M.; Laurier, D.; Rage, E. Kidney cancer mortality and ionizing radiation among French and German uranium miners. Radiat. Environ. Biophys. 2014, 53, 505-513. [CrossRef]

91. Chen, B.; Yuan, T.W.; Wang, A.Q.; Zhang, H.; Fang, L.J.; Wu, Q.Q.; Zhang, H.B.; Tao, S.S.; Tian, H.L. Exposure to Radon and Kidney Cancer: A Systematic Review and Meta-analysis of Observational Epidemiological Studies. Biomed. Environ. Sci. 2018, 31, 805-815. [CrossRef]

92. Neuberger, J.S.; Pierce, J.T.; Lai, S.M. Cancer cluster investigation in a school district. J. Sch. Health 1997, 67, 380-383. [CrossRef]

93. Kristbjornsdottir, A.; Rafnsson, V. Incidence of cancer among residents of high temperature geothermal areas in Iceland: A census based study 1981 to 2010. Environ. Health 2012, 11, 73. [CrossRef]

94. VoPham, T.; DuPré, N.; Tamimi, R.M.; James, P.; Bertrand, K.A.; Vieira, V.; Laden, F.; Hart, J.E. Environmental radon exposure and breast cancer risk in the Nurses' Health Study II. Environ. Health 2017, 16, 97. [CrossRef]

95. Cohen, B.L. Relationship between exposure to radon and various types of cancer. Health Phys. 1993, 65, 529-531. [CrossRef]

96. ANPA, Agenzia Nazionale per la Protezione dell'Ambiente, ANPA-RT-00-009. Available online: https://inis.iaea.org/collection/ NCLCollectionStore/_Public/32/007/32007841.pdf (accessed on 28 September 2021).

97. McNeill, K.A. Epidemiology of Brain Tumors. Neurol. Clin. 2016, 34, 981-998. [CrossRef] [PubMed]

98. Braganza, M.Z.; Kitahara, C.M.; Berrington de González, A.; Inskip, P.D.; Johnson, K.J.; Rajaraman, P. Ionizing radiation and the risk of brain and central nervous system tumors: A systematic review. Neuro. Oncol. 2012, 14, 1316-1324. [CrossRef] [PubMed]

99. Kendall, G.M.; Smith, T.J. Doses to organs and tissues from radon and its decay products. J. Radiol. Prot. 2002, 22, 389-406. [CrossRef]

100. United Nations Scientific Committee on the effects of atomic radiation. Available online: https://www.unscear.org/docs/ publications/2013/UNSCEAR_2013_Report_Vol.II.pdf (accessed on 28 September 2021).

101. Harley, N.H.; Robbins, E.S. Radon and leukemia in the Danish study: Another source of dose. Health Phys. 2009, 97, $343-347$. [CrossRef] [PubMed]

102. Laurier, D.; Valenty, M.; Tirmarche, M. Radon exposure and the risk of leukemia: A review of epidemiological studies. Health Phys. 2001, 81, 272-288. [CrossRef] [PubMed]

103. Eatough, J.P.; Henshaw, D.L. Radon and thoron associated dose to the basal layer of the skin. Phys. Med. Biol. 1992, 37, 955-967. [CrossRef] [PubMed]

104. Eatough, J.P. Alpha-particle dosimetry for the basal layer of the skin and the radon progeny 218-Po and 214-Po. Phys. Med. Biol. 1997, 42, 1899-1911. [CrossRef] [PubMed]

105. Barbosa-Lorenzo, R.; Barros-Dios, J.M.; Ruano-Ravina, A. Radon and stomach cancer. Int. J. Epidemiol. 2017, 46, 767-768. [CrossRef]

106. National Research Council. Risk Assessment of Radon in Drinking Water; National Academies Press: Washington, DC, USA, 1999.

107. Farkas, A.; Hofmann, W.; Balásházy, I.; Szoke, I.; Madas, B.G.; Moustafa, M. Effect of site-specific bronchial radon progeny deposition on the spatial and temporal distributions of cellular responses. Radiat. Environ. Biophys. 2011, 50, 281-297. [CrossRef]

108. Bartsch, H.; Hollstein, M.; Mustonen, R.; Schmidt, J.; Spiethoff, A.; Wesch, H.; Wiethege, T.; Müller, K.M. Screening for putative radon-specific p53 mutation hotspot in German uranium miners. Lancet 1995, 346, 121. [CrossRef]

109. Kennedy, C.H.; Mitchell, C.E.; Fukushima, N.H.; Neft, R.E.; Lechner, J.F. Induction of genomic instability in normal human bronchial epithelial cells by 238Pu alpha-particles. Carcinogenesis 1996, 17, 1671-1676. [CrossRef]

110. Brooks, A.L.; Bao, S.; Harwood, P.W.; Wood, B.H.; Chrisler, W.B.; Khan, M.A.; Gies, R.A.; Cross, F.T. Induction of micronuclei in respiratory tract following radon inhalation. Int. J. Radiat. Biol. 1997, 72, 485-495. [CrossRef]

111. Deshpande, A.; Goodwin, E.H.; Bailey, S.M.; Marrone, B.L.; Lehnert, B.E. Alpha-particle-induced sister chromatid exchange in normal human lung fibroblasts: Evidence for an extranuclear target. Radiat. Res. 1996, 145, 260-267. [CrossRef]

112. Nagasawa, H.; Little, J.B. Induction of sister chromatid exchanges by extremely low doses of alpha-particles. Cancer Res. 1992, 52, 6394-6396.

113. Wu, L.J.; Randers-Pehrson, G.; Xu, A.; Waldren, C.A.; Geard, C.R.; Yu, Z.; Hei, T.K. Targeted cytoplasmic irradiation with alpha particles induces mutations in mammalian cells. Proc. Natl. Acad. Sci. USA 1999, 96, 4959-4964. [CrossRef]

114. Lorenzo-González, M.; Ruano-Ravina, A.; Torres-Durán, M.; Kelsey, K.T.; Provencio, M.; Parente-Lamelas, I.; Leiro-Fernández, V.; Vidal-García, I.; Castro-Añón, O.; Martínez, C.; et al. Residential radon, genetic polymorphisms in DNA damage and repairrelated. Lung Cancer 2019, 135, 10-15. [CrossRef]

115. Lim, S.M.; Choi, J.W.; Hong, M.H.; Jung, D.; Lee, C.Y.; Park, S.Y.; Shim, H.S.; Sheen, S.; Kwak, K.I.; Kang, D.R.; et al. Indoor radon exposure increases tumor mutation burden in never-smoker patients with lung adenocarcinoma. Lung Cancer 2019, 131, 139-146. [CrossRef]

116. Alavanja, M.C. Biologic damage resulting from exposure to tobacco smoke and from radon: Implication for preventive interventions. Oncogene 2002, 21, 7365-7375. [CrossRef]

117. Brenner, D.J.; Sachs, R.K. Do low dose-rate bystander effects influence domestic radon risks? Int. J. Radiat. Biol. 2002, 78, 593-604. [CrossRef] 
118. Azzam, E.I.; De Toledo, S.M.; Spitz, D.R.; Little, J.B. Oxidative metabolism modulates signal transduction and micronucleus formation in bystander cells from alpha-particle-irradiated normal human fibroblast cultures. Cancer Res. 2002, 62, 5436-5442.

119. Iyer, R.; Lehnert, B.E.; Svensson, R. Factors underlying the cell growth-related bystander responses to alpha particles. Cancer Res. 2000, 60, 1290-1298. [PubMed]

120. Azzam, E.I.; Little, J.B. The radiation-induced bystander effect: Evidence and significance. Hum. Exp. Toxicol. 2004, $23,61-65$. [CrossRef] [PubMed]

121. Sethi, T.K.; El-Ghamry, M.N.; Kloecker, G.H. Radon and lung cancer. Clin. Adv. Hematol. Oncol. 2012, 10, 157-164. [PubMed]

122. Sanders, C.L.; Scott, B.R. Smoking and hormesis as confounding factors in radiation pulmonary carcinogenesis. Dose-Response 2006, 6, 53-79. [CrossRef] [PubMed]

123. Brenner, D.J.; Doll, R.; Goodhead, D.T.; Hall, E.J.; Land, C.E.; Little, J.B.; Lubin, J.H.; Preston, D.L.; Preston, R.J.; Puskin, J.S.; et al. Cancer risks attributable to low doses of ionizing radiation: Assessing what we really know. Proc. Natl. Acad. Sci. USA 2003, 100, 13761-13766. [CrossRef]

124. Luckey, T.D. Radiation hormesis: The good, the bad, and the ugly. Dose-Response 2006, 4, 169-190. [CrossRef] [PubMed] 